\title{
Lex Internationalis: Kiobel, Empires, and the Color of Human Rights
}

\author{
P. SEAN MORRIS*
}

\begin{abstract}
In this article, I investigate the nature and origin of the Alien Tort Statute (ATS) and its link and application to the modern conception of human rights. In the recent Kiobel decision, the Supreme Court resurrected the ATS and found that the ATS does not apply to human rights violations outside of the U.S. allegedly committed by foreign-based corporations. The Supreme Court held that the presumption against extraterritorially applies to common law causes of action under the ATS, and no evidence exists that the First Congress wanted the ATS to confer jurisdiction over extraterritorial torts. In the article, I develop the notion of the color of human rights to demonstrate that human rights itself has become a sort of lex internationalis. In recent years a number of cases have emerged in some courts where non-western people of color (aliens), aided and abetted by western self-appointed human rights missionaries, have initiated human rights claims in courts. In what may be characterized as a grand game of "civilizing" and imperial rhetoric, the aliens, are sometimes lead to believe that a debt is owed to them by western civilized nations for great injustices. This is what I refer partly to, as the color of human rights. This is a subjective analysis, based on the Kiobel decision of what was supposed to be David v. Goliath_ "primitive" and "uncivilized" people from other (alien) lands taking on the mighty corporate Goliath with head-quarters in the "civilized nations." The notion of civilized and uncivilized in this article carries two meanings: the first is the usual suspect of the global North/South divide, and the second is to distinguish the behaviors of people regardless of their citizenry, in particular their interpretation of and approach to humanizing the practice and regime of human rights. In the article, I review the historical development of the ATS and the notion of civilization to demonstrate that the ATS was not a tool for today's aliens of color but was meant to appease the "civilized" states of eighteenth century Europe. The article offers a critical look at the Kiobel case and argues that the core human rights concerns were disposed of. I used the history and development of "civilized" (empire) and the "uncivilized" (former subjects of empire) to describe the historical operation of the ATS, and how it is transposed into contemporary buman rights cases.
\end{abstract}

* University of Helsinki, Affiliated Research Fellow, Erik Castren Institute of International Law \& Human Rights. This paper was first presented as part of the international law and human rights panel in the workshop of Law in a Changing World annual meeting at the Lammi Biological Station, Finland, March 10-11, 2014. I would like to thank the participants and commentators for their feedback. I am also grateful to the staff of the Georgetown Journal of Law \& Modern Critical Race Perspectives for their assistance in bringing this article to publication. The views expressed in this article represent those of the author alone. (C) 2014, P. Sean Morris. 


\section{TABLE OF CONTENTS}

I. The EMPIRE of Civilization, LaWs, AND NeW Nations . . . . . . .

II. ATS ORIGINS: UNCIVILIZED BEHAVIORS AND THE NEED FOR

Civilized Rules AMONG NATIONS . . . . . . . . . . . . . . 77

A. The "Uncivilized" Insults of the French Ambassador in $1784 \ldots . . .78$

B. The Invasion of the Dutch Diplomatic Residence in $1787 \ldots$. . . . 80

C. Privateers, Empires, and the High Seas . . . . . . . . . . 81

III. "Negroes" and Modern "Coloreds"-The Language, Real

ORIGINS, AND TESTING OF THE ATS . . . . . . . . . . . . 83

A. Spoils of War: Captain Bolchos and the Cargo of Negroes........ 86

B. Blackness, the Law of Nations, the ATS, and the Sierra Leone Predicament ......................

C. Browness, the Law of Nations, and How the ATS Met Filartiga and Sosa ........................ 91

D. God, the ATS, and the Oil Fallacy in Sudan . . . . . . . . . . . . 94

IV. IS HUMAN RigHTS LEX INTERNATIONALIS? KIOBEL, THE ATS, AND THE LAW OF NATIONS . . . . . . . . . . . . . . . . 95

A. Background to the Kiobel Litigation in the Supreme Court . . . . . 96

B. The Supreme Court and the Effort to Minimize International Discord in Kiobel . . . . . . . . . . . . . . . . . 97

C. Lex Internationalis and the Color of Human Rights . . . . . . . . 100

V. Conclusion ...................... 106

\section{The EMPiRE of Civilization, LAWS, AND NeW NATIONS}

In 1789, a young United States of America was celebrating its thirteenth year of independence. It was the year the young republic molded itself with the law of nations. ${ }^{1}$ When the U.S. was still thirteen colonies, a group of like-minded "mercantilists," who held power in the thirteen colonies, believed it was a good idea to pursue an American mercantilism through a free state independent of the British rule. They

1. "Upon ratification of the Constitution, the thirteen former colonies were fused into a single nation, one which, in its relations with foreign states, is bound both to observe and construe the accepted norms of international law, formerly known as the law of nations. Under the Articles of Confederation, the several states had interpreted and applied this body of doctrine as a part of their common law, but with the founding of the more perfect Union of 1789 , the law of nations became preeminently a federal concern," Filartiga v. Irala-Pena, 630 F.2d 876, 877-78 (2d Cir. 1980). 
declared their independence from England in 1776 and began a journey to pursue the ideals of mercantilism to bring prosperity to their countrymen.

Some thirteen years later, inspired by continental nations such as France, the American legislature enacted a law that allowed the young nation's courts to recognize private claims for suspected violations of the laws of nations. However, 1789 was not a good year for the U.S. as it became embroiled in a number of international legal incidents. For example, France had declared war on England, the Americans were still in the midst of negotiating the Jay Treaty, ${ }^{2}$ and Britain was continuously seizing American ships. These ongoing troubles required legal attention, and legal luminaries in the judiciary and government were still relying on the English common law and the teachings of European scholars. ${ }^{3}$ However, it was the teachings of Emer Vattel that had more impact on the young nation's lawyers as they relied heavily on his concept of the law of nations.

Vattel's Law of Nations was the international law book of the time and drafters of the Judiciary $\mathrm{Act}^{4}$ embraced the positivism of international law and included the Alien Tort Statute ("ATS") in the Judiciary Act. ${ }^{5}$ The ATS is a procedural legal instrument, and its primary purpose was to enable foreigners who legally settle in the U.S. to sue in U.S. courts for torts committed abroad that violated the law of nations. Although the ATS is a jurisdictional statute that conferred jurisdiction in U.S. courts, it was aimed at European aliens present in the new nation and was not applicable to the "sub-humans" who were used as slaves or other people of color who were not of European descent. The French and the Dutch can be credited for the ATS; it was a French diplomat who had been assaulted in Philadelphia, and, in New York, a policeman violated the diplomatic premises of the Dutch diplomatic envoy. But outside of these incidents, more pressing issues of international law during this period, such as piracy, can also be credited for the ATS's passage. The ATS was designed to provide relief for injuries suffered by (European) aliens and to avoid messy diplomatic rows with the young nation's foreign partners.

After more than two hundred years, during which time the ATS laid mostly dormant, the statute was revived as a human rights tool by aliens of color, both in

2. Treaty of Amity, Commerce, and Navigation, signed at London November 19, 1794.

3. Such scholars included Emer de Vattel (1714-1767), whose Law of Nations treatise was a sourcebook on how international affairs should be conducted and influenced the Founding Fathers and the new vision of young America. See VinCENT CHETAIL, Vattel and the American Dream: An Inquiry into the Reception of the Law of Nations in the U.S., in, LES FONDEMENTS DU DROIT INTERNATIONAL [THE ROOTS OF INTERNATIONAL LAw] 251 (Pierre-Marie. Dupuy eds., 2013); Jesse Reeves, The Influence of the Law of Nature Upon International Law in the U.S., 3 AM. J. I. L. 547 (1909); Brian Richardson, The Use of Vattel in the American Law of Nations, 106 AM. J. I. L. 547 (2012).

4. This was as a result of the first legislative act in the First Congress sitting of the Senate, where that Chamber's Bill No. 1 became the Judiciary Act of 1789, Act of Sept. 24, 1789, ch. 20, 1 Stat. 73. Codified and amended at 28 U.S.C. $\$ 1350$.

5. See e.g., Sosa v. Alvarez-Machain, 542 U.S. 692, 722 (2004) (where the Supreme Court discussed the relationship between common law and positive law in the eighteenth century, noting that "positive law was frequently relied upon to reinforce and give standard expression to the brooding omnipresence of the common law then thought discoverable by reason (citation and quotation omitted)." See also, Ernest A. Young, Foreign Courts and Foreign Affairs, 42 VA. J. INT'L L. 365 (2002). 
and outside of the U.S. A number of cases where the ATS was used for claims of violating the law of nations was brought before American courts, including the recent Kiobel decision, which questioned the nature of international law and the application of U.S. law extraterritorially. ${ }^{6}$ These cases suggest that the shadows of empire still hang over the modern legal reasoning used whenever the ATS is involved.

In a highly thoughtful text, The Empire of Civilization: The Evolution of an Imperial Idea, ${ }^{7}$ Brett Bowden examined concerted attempts to "inculcate civilization in all corners of the globe" thereby "expanding the empire of civilization." 8 Although Bowden's text was written as a classic text in the political science discipline, it has been applied in the international law realm primarily because of Bowden's interdisciplinary approach. ${ }^{9}$ The notion and concept of civilization in international law has been notoriously plagued, riddled with class, hierarchy, race and development. In essence, civilization was always meant to distinguish the Europeans from others, and, in this context, international law has developed along this line. ${ }^{10}$ At the top of the hierarchical pyramid were the Europeans-the White Knights on a path to save humanity from itself, from barbaric atrocities, and, most importantly, to "civilize" others, in particular non-Europeans. Up until the fourteenth century, before Italian explorer Christopher Columbus set sail to find the Orient, Europeans were largely associated with other states in Europe or were at war with each other, ${ }^{11}$ while other empires were being cemented along ethnic intra-European cultural lines. ${ }^{12}$ In the middle of the civilized hierarchical pyramid were the Arabs and Asians. The former were perceived by Europeans as a sort of near-civilized people due to their ancient history and scientific discoveries in Mesopotamia, while the latter were seen as an enigmatic group of people found in the Orient. At the bottom of this civilized hierarchical pyramid were the "negroids," found mostly in Africa, a near sub-human species (or probably hostis humani generi, enemies of the human race) whose development and progress in the world was so far behind that of Europeans that they were viewed as little more than tropical animals capable of enduring torture through forced labor. This group was able to communicate in human form, and held at least that distinction over four-legged animals. From the fifteenth to nineteenth century, this group would toil in European and American plantations in the New World that Columbus stumbled upon and initially thought was the Orient.

\footnotetext{
6. Kiobel v. Royal Dutch Petroleum Co., 133 S. Ct. 1659 (2013).

7. Brett Bowden, The EMPire of Civilization: The EVolution of an IMPERIal Idea (2009).

8. Id. at 1-2; see also, Thomas Mccarthy, Race, Empire and the Idea of Human Development (2009); Costas Douzinas, Human Rights And Empire: The Political Philosophy of CosmopolitanISM (2007).

9. Bowden, supra note 7 , ch. 5 generally.

10. Id. at 16 , noting that: "The standard of civilization is essentially a means of distinguish between civilized and uncivilized nations or peoples in order to determine membership in the international society of states."

11. For example, the Thirteen Year's War (1454-1466) involved Prussia and the Teutonic Order.

12. The Holy Roman Empire (962-1806) was one such example.
} 
Once Europe was aware of the new world, the lands were rapidly conquered and carved up among European nations and empires (even though some were still at war with each other). Having gained new lands across the Oceans, Europeans filled the new lands with barbaric and uncivilized negroids from the dark continent; the American natives were incapable of producing the exotic goods in record number, thus Europe borrowed the slavery tradition from Ancient Rome and transported captured Africans across the Atlantic Ocean and transposed them on the plantations of the new world. A massive industry in transporting slaves across the Atlantic emerged and the Atlantic Slave Trade ensured that the European states would progress further in their developments to become figuratively on top of the world. At this height of development, European powers realized their need for peace, and the great conference of Westphalia (1646-1648) produced a series of treaties to end all European wars. A number of other conferences were held over the next two centuries to resolve smaller conflicts.

Peace in Europe allowed its citizens to focus on the Arts, Theology, Philosophy, Law, and the Natural Sciences. This new period of cultural enlightenment had repercussions in the New World, and by the late sixteenth century, one of Europe's greatest empires, the British Empire, saw the effect of new ideals in the thirteen colonies. European descendants who lived in the thirteen colonies began to argue for equality comparable to that of their European forefathers, and they were also growing discontent with the King of England and his taxes on the thirteen colonies. In Europe, the new religion, enlightenment, produced a Swiss disciple, Emer de Vattel, who penned the scriptures of the Law of Nations (a resurrection of legal traditions from the Roman Empire) ${ }^{13}$ and launched a moralist campaign of what could be termed human rights against the unconstitutionality of slavery (presumably to redeem his sins, as Vattel himself was at one point a champion of mercantilism using slave labor). ${ }^{14}$ Vattel's work drew admirers in the thirteen colonies, including Thomas Jefferson, ${ }^{15}$ and by the eighteenth century, conspirators in the thirteen colonies declared their independence from the British Empire.

The United States of America was quickly recognized by a number of European states such as France and Holland. Furthermore, the U.S. was aligned with European

13. Harold Berman, The Alien Torts Claim Act and the Law of Nations, 19 EMORY INT'L L. REV. 69, 71 (2005) ("The term law of nations is, of course, the English translation of the ancient Roman term jus gentium, which was first used to signify the law of the conquered peoples of the Roman Empire, as contrasted with the jus civile, the law of the citizens of Rome. In the first century A.D., however, the jus gentium came to be combined with the jus civile, [. . .."). See also Genc Trnavci, The Meaning and Scope of the Law of Nations in the Context of the Alien Torts Claim Act and International Law, 26 U. PA. J. INT'L ECON. L. 193 (2005).

14. See Jean Allain, Slavery in International Law: Of Human Exploitation and Trafficking $50,(2012)$, noting that although Vattel tried to distance himself from slavery, "he does in fact allow for enslavement".

15. Berman, supra note 13, at 74 ("When the U.S. of America declared its independence in 1776 and became first a confederation and later a federal union, great leaders such as James Madison, Alexander Hamilton, Thomas Jefferson, Oliver Ellsworth, and James Wilson, all understood and accepted the concept of the law of nations [. . ] it is no exaggeration to say that most of them were steeped in the writings on the law of nations of Hugo Grotius and his 18th-century successors, especially the Swiss jurist Emmerich de Vattel [...]."). 
ideals, and as such, its citizens were European, and, in this regard, the nation allowed slavery to continue and deprived the sub-humans who plowed the lands of the same rights as European Americans. The new nation was also a civilized nation and considered itself to be equal to the old nations of Europe. To be civilized as a people and as a society was equivalent to the notion of being European or of European descent. The language of civilization was the rhetoric of exclusion; this language did not apply to non-Europeans. To be civilized was to ensure a seat at the top of the hierarchical pyramid and secure a position as a leader in the emerging international society composed largely of European states.

Vattel's work had a serious impact on the legal thought of early American leaders and legal institutions. Vattel championed the law of nations, particularly the notion of customary international law, which the Americans were keen on adopting even if it conflicted with the nation's ideals of democracy and the free-market spirit. For Vattel, the law of nations was "the science which teaches the rights subsisting between nations or states, and the obligations correspondent to those rights." ${ }^{16}$ Similarly, another European, Blackstone, years of birth and death in brackets: "[17231780]" was also influential in the development of the law of nations, though he referred to it as international law. Blackstone saw international law (eighteenth century law of nations) as "a system of rules, deducible by natural reason and established by universal consent among the civilized inhabitants of the world" ${ }^{17}$ and as something that self-metamorphosizes in common law, therefore becoming "part of the law of the land." Blackstone was primarily referring to English common law, and the U.S. retained that system and thus saw international law as "self-executing." These teachings helped shape the young country's conception and execution of the law of nations. ${ }^{18}$ Although the new nation was preoccupied about refining its own state and governance, it had no intention of creating an empire similar to the one it had recently separated from, but there was no doubt that the young republic saw itself as civilized and on equal terms with Europe.

As the U.S. developed its institutions and judiciary after declaring its independence, it was still largely influenced by European traditions. ${ }^{19}$ The English common law was retained, and a quasi-system of civil law developed alongside the common law. This peculiarity makes American law completely unique even to the present day. To Americans in the eighteenth century, foreign relations consisted of dealings with Europe and the British Empire. In order not to antagonize the British and the

16. Also cited in Sosa, infra note 20 , at 714 .

17. $4 \mathrm{~W}$. Blackstone, Commentaries 66-67 (1978); In the late eighteenth century, another influential British jurist Jeremy Bentham, began a pseudo crusade for the move from the law of nations to that of international law, see e.g., INTRODUCTION TO THE PRINCIPLES OF MORALS AND LEGISLATION (1789).

18. Sosa, infra note 20, at 714: "In the years of the early republic, this law of nations comprised [. . .] the general norms governing the behavior of national states with each other [. . ] or that code of public instruction which defines the rights and prescribes the duties of nations, in their intercourse with each other" (citations and quotations omitted).

19. Berman, supra note 13, 75: "The leaders of the new American Republic were under great pressure to show Britain, France, Holland, and other European nations that both the individual states and the union claimed their rights and accepted their responsibilities under the law of nations." 
Europeans, one of America's earliest laws, the Alien Tort Statute, was passed as part of the Judiciary Act, and it still remains on the books today. The ATS was created to ensure that Europeans present in America or those who had diplomatic and business engagements with the new nation were guaranteed a means of legal remedy in the event they were wronged.

\section{ATS ORIGINS: UNCIVILIZED BEHAVIORS AND THE NEED FOR CIVILIZED RULES AMONG NATIONS}

The ATS can be seen as legislation of and for being civilized. The only connection the ATS has with slavery (and thus human rights from a non-Eurocentric perspective, as I will argue later) was interpreted as outlawing piracy, in particular where slave ships were raided or suspected of being used to raid the ships of the trading partners of the new nation on the high seas. Primarily these trading partners were the British Empire and other European states such as France, Spain, Holland, and Portugal. But, as time marched on, and slavery was abolished, the ATS lay dormant for more than two hundred years, and in the modern era of international law, human rights have become an area of increasing importance and debate. Amidst this, the ATS was revived in American courts, not as a way of dealing with inviolability, piracy or the trading relations of European States (for which the ATS was originally meant), but, rather, was applied by the descendants of those who were once enslaved, their distant cousins in the "dark continent," and other people of non-European origin. ${ }^{20}$ This new interpretation of the ATS was to be used as a tool to seek remedy for alleged aiding and abetting of human rights violations by western-based corporations against mostly people of color, the "uncivilized." 21 These developments are an ironic twist of events and thrust the color of human rights into the international spotlight. It was therefore no coincidence that when the U.S. Supreme Court was asked to rule on an alleged violation of human rights against "uncivilized" people in the Delta region of Nigeria, the Court had no choice but to find that the ATS does not apply extraterritorially. In arriving at this decision in Kiobel, the Court ignored the notion of human rights and instead turned to a doctrinal debate surrounding foreign policy considerations.

But, the foreign policy considerations hearken back to the eighteenth century, prior to the passage of the ATS. Major cities such as Boston, New York, and Philadelphia were littered with Europeans who were either acting as emissaries of their governments, spying, providing military advice, setting up trading outposts, engaging in the process of shipping slaves across the Atlantic, private military contracting (by privateers), or other Europeans who were castaways due to their support for the U.S. during its war of independence. Two incidents that concerned Europeans required the ATS, and the ATS enabled the new nation to demonstrate to its Euro-

20. Tel-Oren v. Libyan Arab Republic, 726 F.2d 774 (D.C. Cir. 1984), cert. denied, 105 S. Ct. 1354 (1985); Filartiga v. Pena-Irala, 630 F.2d 876 (2d Cir. 1980) (court found that a Paraguayan police official who tortured another Paraguayan violated international law); see also Sosa v. Alvarez-Machain, 542 U.S. 692 (2004).

21. Kiobel, supra note 6 . 
pean allies that the U.S. was part of the international civilized society. On the first occasion, a French ambassador was insulted on the streets of Philadelphia in 1784, and on the second occasion, in 1787, police in New York violated the diplomatic residence of a Dutch delegation. These incidents were not fit for a civilized nation, and the U.S. knew that measures were needed to ensure (a) it would be a civilized nation similar to its European allies and (b) the promulgation of legal rules that cater to incidents like these, so that Europeans could rest assured that normal trading and diplomatic ties would not be jeopardized. All of these incidents were critical to the passage and later interpretation of the ATS and the law of nations in relation to (1) violation of safe conduct, (2) infringement of the rights of ambassadors, and (3) piracy. The ATS was therefore not meant to offer judicial reprieve to the uncivilized, in particular, during a period in which slavery was the norm in the fledging republic, but rather, the ATS was designed to remedy small torts ${ }^{22}$ pertaining to Europeans based in the U.S. in the eighteenth century.

In the next three sections, I want to provide a richer, albeit somewhat subjective, understanding of the eighteenth century affairs surrounding the passage of the ATS and how those events influenced modern opinions, such as Kiobel, applying the ATS, in particular when "civilized" and "uncivilized" people and nations tried to use the ATS for tortful wrongs and heinous injustices.

\section{A. The "Uncivilized" Insults of the French Ambassador in 1784}

Prior to the passage of the ATS, some of the known reported incidents or attacks on European nationals who were present in the new American republic were targeted mostly at diplomats. When Francois Barbe-Marbois (1745-1837), the local delegate to the French legation, was insulted on the streets of Philadelphia it was an act that went beyond the norm of a civilized nation. The French statesman was known for the Louisiana Purchase, ${ }^{23}$ having sold the French territory to the U.S., during the Revolutionary period in America, and France was a staunch ally of the American quest for independence from Great Britain. Besides, Britain was France's staunchest enemy on the high seas, in trade and commerce, and the slave trade. France, for its part, was prepared to do anything to hurt the British, including supporting young America's claim to British North American possessions.

Furthermore, the Revolutionary War coupled with "the French-American Alliance of 1778 offered office seekers a chance to earn salaries as diplomats and consuls representing France in the new U.S." ${ }^{24}$ The new American republic was also a source of intrigue and exploration, and, thus, French enthusiasts would simultaneously

22. Peter Henner, Human Rights and the Alien Tort Statute: Law, History, and Analysis, ix (2009) ("The statute was designed in 1789 to provide a remedy for a very small category of torts-to provide assurances to other countries that the U.S. would be able to adequately redress any insults to ambassadors and diplomats from foreign countries.").

23. See generally, Empires of the Imagination: Transatlantic Histories of the Louisiana PurCHASE, (Peter Kastor \& Francois Weil eds., 2009).

24. David Nichols, A Rejoinder to Jefferson's Notes on Virginia: Francois Barbe de Marbois in Iroquoia, 1784, 84 New York History 389 (2003); see also, Paul Cheney, A False Dawn for Enlightenment Cosmopolitanism? Franco-American Trade during the American War of Independence, 63 THE WILLIAM \& MARY Q. 463 (2006) 
pursue diplomacy, exploration, and "economic speculation." 25 Marbois had been appointed in 1779 to a diplomatic post in the U.S., having honed his diplomatic skills in Germany, and he spent most of his early years in low level functions at the French legation in Philadelphia, ${ }^{26}$ using his connection with the then-Governor of Virginia Thomas Jefferson for exploring and studying the native Indian population. By 1784, Marbois married Elizabeth Moore and, in the same year, was insulted in Philadelphia where he served as consul, consul general and charge de affairs from 1781-1784.

By the late spring of 1784, the U.S. had an influx of Europeans, and one such adventurer was Charles "Chevalier" De Longchamps, a French national, who "verbally and physically assaulted" Marbois. ${ }^{27}$ Longchamps' initial assault on Marbois was in the diplomatic residence of the French legation where Longchamps allegedly verbally insulted Marbois (referring to him as Je vous deshonnerera, Policon, Coquin and also a 'Blackguard') ${ }^{28}$ and days later confronted him on the streets, where he threatened bodily harm. ${ }^{29}$ At one point, Marbois reportedly used a cane to fend off the physical threats from Longchamps in a nearby coffee shop, and diners "interfered and separated the parties" 30 to prevent them from causing bodily harm to one another. Marbois, witnesses claimed, was not entirely civil himself as it appeared he struck the first blow to Longchamps in the coffee house. However, it was clear that two Frenchmen engaged in uncivilized behavior both on their diplomatic premises and later on the Philadelphia streets in the spring of 1784. Acting on European presumptions of civility, Marbois believed civilized nations should not tolerate such acts, and this presumably included the new nation of America.

Marbois protested the uncivilized acts committed against him that took place on U.S. soil and wanted Longchamps deported. The case came up before the Pennsylvania courts and later the Supreme Court, which labeled the case as one of "first impression in the U.S." ${ }^{31}$ The Chief Justice turned to the law of nations to find a

(noting that the 1778 treaty was more "an attempt to strip Britain of its North American possessions and trade in compensation for the French losses in the Seven Years' War").

25. Nichols, supra note 24 , at 390.

26. Id. at 392 .

27. Sosa, supra note 20, at 717 (citing Respublica v. De Longchamps 1 U.S. 111 (1784)). Note that the case was initially heard at the Court of Oyer and Terminer in Philadelphia. However the citations for these courts are the same as those for the U.S. Supreme Court. Thus, I will refer to the Oyer court when citing the initial trial of the case, where most of the facts on the incidents are described in more detail.

28. The French is loosely translated as: "I will dishonor you, you naughty rascal!" Chief Justice McKean would later opine: "words are now to be taken according to their ordinary import and meaning," and those words "are evidently of a tendency so opprobrious and violent, that they cannot fail to aggregate the outrage which has been committed." The Extraterritorial Effect of Respublica v. De Longchamps, THE VIEW FROM LL2 (May 28, 2013), http://viewfromll2.com/tag/longchamps/.

29. Oyer Court, supra note 27, at 111 ("Longchamps [. . ] unlawfully and insolently did threaten and menace bodily harm and violence [...] [in the diplomatic residence of the Ambassador] and under the protection of the law of nations [...] [and] in the public street he the said Charles Julian de Longchamps unlawfully, premeditatedly and violent, in and upon the person of the said Francois Barbe Marbois under the protection of the laws of nations.").

30. Id.

31. Respublica, supra note 27 , at 114. 
remedy and noted that there was "no doubt, that those laws have been violated." 32 The French diplomatic residence, the Supreme Court explained, was considered "Foreign Domicil" beyond the reach of municipal laws. ${ }^{33}$ Longchamps was found guilty and during his sentencing, the Supreme Court explained that under the laws of nations, Longchamps was "guilty of a crime against the whole world." 34 There were two distinct components in the case: (1) verbal assault (slander) and (2) physical assault. The courts used both international law (law of nations) and domestic law (municipal law) to respond to these elements in the case, as the former was part of the latter. Both components could have been addressed appropriately under domestic law rather than the law of nations, but the situation was indeed unique because there were two foreign nationals involved. Moreover, the U.S. was keen on showing that it was in full concordance with the law of nations. This was a telltale sign of what was to come in Kiobel more than two hundred years later: foreign relations with states should not be jeopardized.

\section{B. The Invasion of the Dutch Diplomatic Residence in 1787}

Similar to the Marbois case, where the Court held that diplomatic residences of ambassadors and their household were inviolable, the second notorious occurrence which led to the ATS becoming law was the van Berckel affair. In this incident, a New York policeman entered the diplomatic premises of the Dutch Ambassador to arrest a member of his household. ${ }^{35}$

Pieter Johan van Berckel (1725-1800) was the Dutch envoy in New York City in 1787, a position he held from 1783 until 1788 as the first Dutch envoy to the new American republic. The van Berckel affair has not been widely explored in most of the discussions that have cited it, and there are only sparse references and discussions about the incident. For instance, in the Sosa decision, the Supreme Court described

32. Id.

33. Id ("It must be determined on the principles of the laws of nations, which form a part of the municipal law of Pennsylvania; and, if the offences charged in the indictment have been committed, there can be no doubt, that those laws have been violated. The words used in the Minister's house, (which is to be considered as a Foreign Domicil, where the Minister resides in full representation of his sovereign, and where the laws of the State do not extend) may be compared to the same words applied to the Judges in a Court of Justice.").

34. Id. at 116. ("[Slandering] is an infraction of the laws of Nations. This law, in its full extent, is part of the law of this State, and is to be collected from the practice of different Nations, and the authority of writers. The person of a public minister is sacred and inviolable. Whoever offers any violence to him, not only affronts the Sovereign he represents, but also hurts the common safety and well-being of nations; - he is guilty of a crime against the whole world. [. . . Y You have been guilty of an atrocious violation of the law of nations [...].").

35. See also Theresa Adamski, The Alien Tort Claims Act and Corporate Liability: A Threat to the U.S. 'International Relations, 34 FordHAM INT'L L.J. 1502, 1508-09 (2011) ("The [. . .] incident occurred in 1787, when New York police officers entered the home of a Dutch minister in order to arrest a domestic servant, violating the minister's diplomatic immunity. Again, due to the inadequacies of U.S. federal law, the Continental Congress could only ask the state of New York to address the offense. The Mayor of New York complied with Congress' wishes to prosecute, but expressed concern to the US Secretary of State, John Jay, that the U.S. Congress and the New York legislature had yet to address the breach of privileges of ambassadors. Moreover, this crime fell under the law of nations, which was not yet part of U.S. law."). (citations and quotations omitted). 
the incident as merely a "reprise of the Marbois affair." ${ }^{36}$ The New York City cop in question was John Wessel, who wanted to arrest one of the Ambassador's "domestics," a coachman. It was this invasion of the diplomatic residence of the Ambassador that prompted van Berckel to complain to John Jay, then the Secretary of State, and for the U.S. to provide legal remedies for the violation.

Wessel carried out his audacious act during the middle of the Constitutional Convention that was taking place in the city. ${ }^{37}$ Despite the limited recording of the van Berckel incident in comparison to Marbois' incident, it seemed, from a legal perspective, that the van Berckel affair prompted the enactment of the ATS. The fact that Wessel was found guilty for his invasion demonstrated that the U.S. was determined to show its European friends it was indeed a civilized nation where laws were respected and, moreover, that the law of nations was an integral part of the U.S. common law. Other incidents also led to the passage of the ATS, most of which occurred on the high seas or the territorial waters of the U.S. and involved the trading of certain cargoes to the Americas. These other notorious incidents were crucial to the passage and interpretation of the ATS in the years leading up to its dormancy.

\section{Privateers, Empires, and the High Seas}

In the eighteenth century, at the height of the British Empire, another main concern among European nations was events on the high seas. Crimes, such as piracy, were abundant, and slave ships were routinely used or disguised as pirate ships. Slaves destined for the colonies would sometimes not arrive because they were either captured by pirates and sold to new traders or sunk to the ocean floor after a fight to capture them, or were victimized through other treacherous acts such as pillaging and looting of colonial outposts, which occurred on the high seas. In order to protect their ships, some states would hire privateers, ${ }^{38}$ the historic equivalent of modern private military contractors, to protect their ships and cargo. Henry Morgan (1635-1688) was perhaps the most famous of all privateers when he established his outpost in Port Royal, an enclave in Jamaica, to loot Spanish ships traversing the Caribbean and South American coasts. But by the eighteenth century more Henry Morgans were needed as pirates started looting British, French, Spanish, and Ameri-

36. Sosa, supra note 20, at 717 ("[A] New York City Constable produced a reprise of the Marbois affair and Secretary Jay reported to Congress on the Dutch Ambassador's protest, with the explanation that the federal government does not appear to be vested with any Judicial Powers competent to the Cognizance and Judgment of such Cases.").

37. Brittany Shugart, Relieving the Vigilant Doorkeeper: Legislative Revision of the Alien Tort State in the Wake of Judicial Lawmaking, 22 SOUTHERN CAL. REV. L. SOC. J. 91, 99 (2012) ("In 1787, in the midst of state ratification conventions debating the Constitution and only fifteen months before the enactment of the ATS, John Wessel, a city constable, went to the residence of Pieter Johan van Berckel, the Dutch minister to the U.S., and arrested one of his servants. Ultimately, state law found Wessel guilty of violating the law of nations and provided remedy, since the national government was not authorized to provide a remedy."). (citations omitted).

38. Travers Twiss, Law Of Nations Considered As Independent Political Communities 373 (1863) (defining privateers as "armed ships which are fitted out by private persons, and sail under a commander, to whom a Belligerent Power has granted a commission to seize and take the ships and goods of the subjects of an Enemy."). 
can ships in the Atlantic. Imperial mercantilism was now threatened and such heinous crimes meant that laws were needed to punish those deemed responsible. The English immediately applied its own criminal laws ${ }^{39}$ while the young U.S. interpreted the law of nations to apply to those crimes. The ATS was part of the federal common law and deemed applicable to crimes involving piracy. ${ }^{40}$

Although privateering was legally distinguishable from piracy, in the sense that privateering was state sanctioned and piracy involved individuals acting on their own, both activities were corrosive to the law of nations as allegations were hurled from one civilized nation against the other for violations. Privateers were engaged in the same conducts as pirates, and privateers who were captured were mostly repatriated to their country of origin. ${ }^{41}$ Thus, the law of nations indirectly criminalized piracy, while its legal counterpart, privateering, was legally sanctioned. The U.S. wanted a remedy for "the actions of any privateers for wrongs perpetrated by them in the United States jurisdiction, and against American privateers for depredations outside its territorial jurisdiction, ${ }^{42}$ and the ATS aided the implementation of such remedies through its creation of a universal jurisdiction of sorts. ${ }^{43}$

After the passage of the ATS, from 1794 to 1797, the Supreme Court ruled on twenty-four cases from French privateering activities alone. ${ }^{44}$ Not all of the cases were published; however, a significant amount of cases during this period suggested that privateering, and its linkage to piracy, was crucial to how the ATS was interpreted. As for hired guns, privateers were able to recruit citizens from any countries, and Americans in particular were favorite recruits by the French privateers. Thus, the Bradford Opinion addressed the involvement of American citizens in the French raid on Sierra Leone, where the then-Attorney General was at best muted on the application of the ATS extraterritorially.

The previous sections developed a contextual framework for the inspiration and enactment of the ATS - the young U.S. was eager to demonstrate its willingness to

39. In addition, in 1708 the British Parliament passed a number of prize acts, which gave statuary right to a portion of vessels taken as prize. These acts also contained instructions to privateers that required prizes be brought to a court for adjudication and maintaining the evidence. See, e.g., 6 Anne, Ch. 37 (1708); Matthew Harrington, The Legacy of the Colonial Vice-Adrniralty Courts (Part II), 27 J. MAR. L. \& COM. 323, 328 (1996).

40. See e.g., Bolchos v. Darrel, 3F. Cas. 810 (No. 1,607) (SC 1795) (where a district court had doubts about admiralty jurisdiction over a suit for damages brought by a French privateer against the mortgagee of a British slave ship was assuaged by assuming that the ATS was a jurisdiction basis for the court's action).

41. See Eugne Kontorovich, The Piracy Analogy: Modern Universal Jurisdiction's Hollow Foundation, 45 HARV. INT'L L.J. 183, 210-211 (2004) ("From the seventeenth century through the nineteenth century, nations would issue license called letters or marque and reprisal to private vessels. The letters permitted the bearer, known as a privateer, to stop and seize ships and cargo on the high seas. All nations acknowledged the right of other sovereigns to authorize privateering. Privateering was such a staple of maritime activity it is enshrined in the U.S. Constitution, which explicitly gives Congress the right to authorize commerce raiding."). See also, Carl Kulsrud, Maritime Neutrality To 1780: A History Governing Neutrality AND BeLligerenCY To 1780, 37 (1936) (discussing the origins of privateering); Theodore M. Cooperstein, Letters of Marque and Reprisal: The Constitutional Law and Practice of Privateering, 40 J. L. \& C. 221 (2009).

42. Gerald McGinley, Of Pirates and Privateers - The Historical Background of the Alien Tort Claims Act with Sorne suggestions for its Future Use, 21 ANGLO-AM. L. REV. 138, 147 (1992).

43. E.g, U.S. v. Peters, 3 U.S. 121 (1795) (a case concerning jurisdiction and privateering).

44. David Sloss, Judicial Foreign Policy: Lessons from the 1790s, 53 ST. Lous UNI. L. J. 145, 147 (2009). 
prevent assault on ambassadors and also to prevent piracy. In Sosa, the Supreme Court confirmed, in part, this understanding of the purpose of the ATS and explained that:

an assault against an ambassador, for example, impinged upon the sovereignty of the foreign nation and if not adequately redressed could rise to an issue of war. [...] It was this narrow set of violations of the law of nations, admitting of a judicial remedy and at the same time threatening serious consequences in international affairs that was probably on the minds of the men who drafted the ATS with this reference to tort. ${ }^{45}$

But these events took place during the eighteenth century, and the ATS essentially slipped into oblivion. The legal world would not encounter the ATS for another two hundred years.

Over the next two hundred years, the judicial universe changed dramatically. Legal slavery ${ }^{46}$ was no longer, and piracy, as it had existed in the eighteenth century, had all but vanished. It was rather surprising when the ATS resurfaced, having been dormant; it was likened to German folklore, a legal Lohengrin.

\section{III. "Negroes" and Modern "Coloreds"-The Language, Real Origins, AND TESTING OF THE ATS}

Judge Friendly, once mystified at the existence of the ATS, described it as a "legal Lohengrin" ${ }^{\prime \prime 7}$ given its sudden reappearance after it had been largely ignored for two centuries. Judicial watchers, including Justice Friendly, had good reasons to believe that the ATS had disappeared. First, piracy on the high seas no longer existed, and, second, diplomatic and international discords were now being settled by means other than the ATS. The time and space of the law of nations had changed, and a new version of the law of nations was being applied as international law. Thus, the ATS disappeared from the legal literature because it was a relic of the eighteenth century with little or no practical use. In addition, its language was opaque, terse, and sparse.

But was there a more obscure origin of the ATS that continues to baffle scholars with its elusive language? Or was the real origin of the ATS something that has been a source of guilt? Something too sensitive to discuss in the American legal literature? Or does it take an author of color, including this one, to expose the sensitive origins of the ATS? When the First Congress of the U.S. convened, it passed the Judiciary Act containing the ATS in the fall of $1789 .{ }^{48}$

45. Sosa, supra note 20 , at 715 .

46. But see, Doe I v. Unocal Corp., 395 F. 3d 932, 946 (2002) (noting that forced labor was a modern variant of slavery).

47. See generally IIT v. Vencap, Ltd., 519 F.2d 1001, 1015 (2d Cir. 1975) ("This old but little used section is a kind of legal Lohengrin; although it has been with us since the first Judiciary Act . . no one seems to know whence it came."). A Lohengrin is a hero-knight of medieval Germanic legends. See also, ANNA LOUISE Frey, The Swan-Knight Legend: Its Background, Early Development, And Treatment In The German Poems (1931); Andrea Bianchi, International Law and US Courts: The Myth of Lohengrin Revisited, 15 EuR. J. INT'L L. 751 (2004).

48. First Congress, Session 1, Judiciary Act of 1789, Ch. 20, 1 Stat. 93, September 24, 1789. 
The passage of the Judiciary Act was perceived as an experiment by Congress and as something that would develop over time. ${ }^{49}$ Some scholars have suggested that Madison saw the Judiciary Act itself as defective, and other skeptics saw it as monstrous - as a compromise that was largely dependent upon amendments to Article III of the Constitution. ${ }^{50}$ The ATS, itself, is a unique piece of the American legal institution; it provides district courts with jurisdiction to hear certain claims but does not necessarily provide any cause of action. So as a purely jurisdictional statute, the ATS is somewhat special.

Currently, the full extent of the ATS provides that " $[\mathrm{t}]$ he district courts shall have original jurisdiction of any civil action by an alien for tort only, committed in violation of the law of nations or a treaty of the U.S." 51 This language in the ATS was primarily aimed at European states, because it was with European states that the U.S. primarily negotiated and signed treaties, ${ }^{52}$ and it was primarily European states that had aliens in the U.S.

Slaves during this period were property and were not accorded rights, nor did the U.S. have treaties with African countries from which slaves were primarily sourced. Thus, based on the language of the ATS, if a European had been wronged, there were avenues under the ATS for that wrong to be remedied under the meaning of "for torts only." The ATS has been on the law books since it was passed and has never been amended; however, a number of recodifications resulted in the shifting and interpretation of the meaning of "for torts only." 53

The language of the original version of the ATS is somewhat murky. For example, one source described the original ATS in Section 9 of the Judiciary Act to read as follows; "[a] nd [the district courts] shall also have cognizance, concurrent with courts of the several states, or the circuit courts, as the case may be, of all causes where an alien sues for a tort only in violation of the law of nations or a treaty of the U.S." 54 Ristau then posed the all-important question: "Why this solicitude of the First

49. For example, Congressman Fisher Ames summed up some of the debates surrounding the passage of the Judiciary Act, as "an experimental law [. . . [passed] in the confidence that a short experience will make manifest the proper alterations." Wythe Holt, To Establish Justice: Politics, the Judiciary Act of 1789, and the Invention of the Federal Courts, 38 DUKE L.J. 1421, 1516 n. 354 (1989). Holt also gave a political historicism of the debate surrounding the Act. Id. at 1477-1515. Other skeptics at the time of the passage of the Judiciary Act viewed it as defective and monstrous. Id. See generally, Jide Nzelibe, Contesting Adjudication: The Partisan Divide over Alien Tort Statute Litigation, 33 NW. J. INT'L L. \& BUS. 475 (2013).

50. Charles Warren, New Light on the History of the Federal Judiciary Act of 1789, 37 HaRv. L. REV. 49, 54 (1923); see also Anne-Marie Burley, The Alien Tort Statute and the Judiciary Act of 1789: A Badge of Honor, 83 AM. J. INT'L L. 461 (1989).

51. 28 U.S.C. $\$ 1350$ (1948).

52. E.g., Treaty of Alliance with France: Franco-American Treaty (1778).

53. See e.g., Jeffrey van Detta, Some Legal Considerations for E.U. Based MNEs Contemplating High-Risk Foreign Direct Investments in the Energy Sector after Kiobel v. Royal Dutch Petroleum and Chevron Corporation $v$. Naranjo, 9 S.C. J. INT'L L. \& Bus. 161, 229 (2013) (discussing the nature of “for torts only.").

54. Bruno A. Ristau, The Alien Tort Act, in ASIL Proceedings, The Subject Matter Jurisdiction and Foreign Governments: Act of State, Sovereign Immunity, and the Alien Tort Statute, 80 ASIL 226 (1986); see also M. Anderson Berry, Whether Foreigner or Alien: A New Look at the Original Language of the Alien Tort Statute, 27 BERKELEY J. INT'L L. 316 (2009). 
Congress for the right of aliens?" 55 Although Ristau answered this question by noting, "the drafters did not intend it to provide a jurisdictional basis for suits against foreign states, ${ }^{156}$ he had failed to provide a historical context of the ATS from the notion of civilization and foreign relations with European states in the late eighteenth century. Furthermore, Ristau, like many scholars who wrote about the ATS, did not infuse the notion of slaves or non-civilized people as a context for the ATS origins.

Nevertheless, because the U.S. was founded on certain constitutional ideals, it was a priority for the First Congress to get its judicial affairs in order, and the Judicial Act was seen as setting such affairs in conjunction with the Constitution. Article III sets the framework for the Judicial Act and vests judicial power with the courts. ${ }^{57}$ Section 2 of Article III contains language about foreign relations, the high seas, and treaties. ${ }^{58}$ The Article is, however, a cobweb when it comes to issues regarding ATS cases, particularly if a case involves an American citizen under the "alienage diversity" jurisdiction. ${ }^{59}$ Thus, when the then-Attorney General Bradford was confronted with the involvement of American citizens in the pillaging of Sierra Leone, he suggested that those who suffered from such "acts of hostility" could seek action under the ATS. Before turning to that Opinion, I will first examine spoils of war to illustrate the color of human rights narrative that I later develop in this article. But more importantly, the arguments and events that I discuss in the sections below trace the actual origins and interpretation of the ATS once it was passed primarily for the regulation and trading in slaves. I will explain that the dormancy of the ATS for the past two hundred years was caused by the abolishment of slavery, which the ATS was designed to regulate. Thus, the ATS has deep roots in slave trading despite attempts to argue otherwise. Another argument I develop in other parts of the discussion is the irony that people of color are using the ATS in contemporary times to try and settle scores with similar people of color.

55. Ristau, The Alien Tort Act in ASIL Proceedings, The Subject Matter Jurisdiction and Foreign Governments: Act of State, Sovereign Immunity, and the Alien Tort Statute, 80 ASIL 226 (1986).

56. Id.

57. US Constitution, Article III, Section 1.

58. See Curtis Bradley, Attorney General Bradford's Opinion and the Alien Tort Statute, 106 AM. J. INT'L L. 2 (2012).

59. Id. at 14 (citations omitted) ("There is an important, but often overlooked, connection between this issue of citizenship and the constitutional authority of the federal courts under Article III of the Constitution to hear ATS cases. An ATS case involving U.S. citizen defendants would fall within the provision in Article III for alienage diversity jurisdiction-that is, jurisdiction over controversies between aliens and U.S. citizens. The Article III basis for hearing ATS suits between aliens is much less clear; at least when the suits involve alleged breaches of the law of nations rather than a treaty. It has long been established that suits between aliens do not fall within Article III alienage diversity jurisdiction. Article III contains specific clauses for certain cases likely to involve law of nations issues, such as cases involving ambassadors and admiralty cases. But outside of those contexts, it is not clear what the Article III basis for jurisdiction would be in an ATS case between aliens."). 


\section{A. Spoils of War: Captain Bolchos and the Cargo of Negroes}

One of the early cases arising immediately after the passage of the ATS, Bolchos $v$. Darrel, $^{60}$ a 1795 South Carolina case, has largely been forgotten or ignored in the legal literature. The case involved the capture of a slave ship and its human cargo. The parties involved in this case were France, Spain, and the U.S. The U.S., as with the enactment of the ATS, was eager to demonstrate to the Europeans that their nation was a law-abiding place with a high regard for the law of nations. Moreover, the U.S. had also declared itself neutral due to the various ongoing wars among the European nations. The dispute occurred when a Frenchman, Captain Bolchos intercepted an enemy ship belonging to the Spanish in open waters and brought it to a port in South Carolina. The ownership of the slaves onboard became the center of the dispute.

The cargo of slaves was mortgaged to a slave trader named "Savage," represented by his agent Edward Darrel. The French seaman was desperate to keep his spoils of war and wanted to sell the slaves. Bolchos sought the help of the court for him to retain his captured prize. The district court denied Bolchos, and he appealed its decision to a federal court which declared that, unlike the state court, the federal court had jurisdiction in the matter under the ATS. ${ }^{61}$ For the federal court, it was important that the U.S. kept its part of the bargain by upholding the law of nations and respecting a treaty it had with France: "Bolchos demands restitution of these negroes, by virtue of the $14^{\text {th }}$ article of our treaty with France. The claimant contends that the Negroes are not within that clause, as they were not on board the prize by the real owner, the mortgagee. " 62 The recognition of the law of nations by the court demonstrated its willingness to be civilized, even though the cause of action surrounded the treatment of humans as property for this was the norm of eighteenth century international law. The court found it unusual that the capture of the ship itself by Captain Bolchos was "colourable"63 and that the slaves as properties were irrelevant, or of "little consequence," since the parties involved were Europeans. The court explained: "The mortgagor is a Spanish subject, and the mortgagee a subject of Great Britain." "The court used this justification to invoke eighteenth century international law. Because the court declared the slaves were property, the court needed to establish nexus with the law of nations and did so by explaining that "the

60. Bolchos v. Darrel, 3F. Cas. 810 (No. 1,607) (SC 1795); see also Thomas Pohl, From Blackbeard to Bin Laden: The Re-Emergence of the Alien Tort Claims Act of 1789 and its Potential Impact on the Global War on Terrorism, 34 J. OF LEG. 77, 80 (2008) (discussing the case and noting in particular: "the true significance of this case is the district court's willingness to hear this tort action via the Alien Tort Claims Act in order to demonstrate to the foreign nationals involved that the U.S. is respectful of treaties and the laws of nations.").

61. Bolchos, supra note 60 , at 810 (" $[\mathrm{T}]$ he court of common law of the state has already dismissed the cause [. . . ] the 9th section of the Judiciary act of congress [. . .] gives this court concurrent jurisdiction with the state courts and circuit court of the U.S. where an alien sues for a tort, in violation of the law of nations, or a treaty of the U.S.").

62. Id.

63. Id. at 811 .

64. Id. at 810; see also, Thomas Pohl, supra note 60, at 81 (noting: "the larger issue is significant-a federal district court afforded a French citizen and a British citizen their day in court and based judgment upon a good faith interpretation of a controlling French treaty."). 
law of nations would adjudge neutral property. ${ }^{\text {"65 }}$ The Bolchos case brought out the full nature of the ATS as a tool for "civilized" Europeans and other European Americans regardless of their status, while slaves or inferiors were only subjects of the ATS. But crucially, this case demonstrated the ATS was a statute that should primarily be interpreted and applied to private tort actions involving property, slaves included.

\section{B. Blackness, the Law of Nations, the ATS, and the Sierra Leone Predicament}

Another test for the ATS came from Attorney General Bradford ${ }^{66}$ in 1795. American citizens were accused of aiding and abetting the French in attacking a British colonial outpost in Sierra Leone. ${ }^{67}$ Piracy was common during that time period as the French, British, and other nations were involved in the tit for tat high seas robbery and raiding of coastal towns. On one occasion, a French fleet embarked on a looting mission of a Sierra Leone coastal settlement, aided and abetted by two Americans involved in slave trading, and the British later protested such trespassing. After a wave of diplomatic correspondences from the British to their American counterparts, the U.S. Secretary of State Edmund Randolph asked the Attorney General for an opinion on the matter. ${ }^{68}$ It was this protest of the "pillaging and destruction of property in Freetown"69 that presented one of the most important interpretations of the ATS. ${ }^{70}$

The interpretation of the ATS by Bradford meant that the application of the ATS was somewhat unclear, when viewed from the perspective of its extraterritorial application to a sovereign country or the reach of the ATS as limited to matters on the high seas only. According to Bradford:

65. Bolchos, supra note 60 , at 811 ("It is certain that the law of nations would adjudge neutral property, thus circumstanced, to be restored to its neutral owner; but the 11th article of the Treaty with France alters that law, by stipulating that the property of friends found on board the vessels of an enemy shall be forfeited. Let these negroes, or the money arising from the sale, be delivered to the libellant. [. . .] there was colourable ground for the defendant's seizing them on behalf of his principal the mortgagee [. . .].").

66. Breach of Neutrality, 1 Op. Att'y Gen. 57 (1795) (hereinafter "The Bradford Opinion" or "Neutrality Opinion").

67. See also Kiobel, supra note 6, at 1667; Curtis, supra note 58, at 10 ("The Bradford Opinion concerned events that had taken place in Sierra Leone in the Fall of 1794. Sierra Leone was a British Colony, consisting primarily of former slaves and others of African descent, many of whom had been freed by the British during the Revolutionary War and had initially relocated to Halifax, Nova Scotia. The colony was managed by the Sierra Leone Company, which was incorporated through an act of Parliament in 1791.”) (citations omitted).

68. Curtis, supra note 58, at 10 (citing Letter from Edmund Randolph to George Hammond, July 6, 1795, U.S. National Archives II, Department of State Records of "Miscellaneous Correspondence-Domestic Letters," Microfilm M40, Roll 8.).

69. Bradford Opinion, supra note 66, at 58 (describing the events as "attacking the settlement, and plundering or destroying the property of British subjects on the coast.").

70. Curtis, supra note 58, at 10 ("A French fleet attacked the Sierra Leone colony in late September 1794, and at least two U.S. citizens were involved in the attack. News traveled slowly back then, and the British government and newspapers did not learn of the attack until early 1795. Soon thereafter, Britain's foreign secretary, Lord William Grenville, 'unofficially' sent a copy of a memorial about it to John Jay, who was still in London after having completed negotiations on the Treaty of Amity, Commerce, and Navigation between the U.S. and Great Britain, also known as the 'Jay Treaty.'”) (citations omitted). 
There can be no doubt that the company or individuals who have been injured by these acts of hostility have a remedy by a civil suit in the courts of the U.S.; jurisdiction being expressly given to these courts in all cases where an alien sues for a tort only, in violation of the laws of nations, or a treaty of the U.S. [. . . . ${ }^{71}$

For Bradford, the ATS offered the best route for redress given that it covered the law of nations as opposed to other legal instruments with a narrow focus such as those punishing crimes like piracy. ${ }^{72}$ The 1790 Piracy Act was not limited to piracy on the high seas but was extended to "any river, haven, basin or bay, out of the jurisdiction of any particular state." Thus, the 1790 Piracy Act had extraterritorial effects beyond the high seas, but Bradford relied only on the ATS instead of the 1790 Piracy Act $^{73}$ as the events involved the relationship between two civilized states, while Sierra Leone was an uncivilized state with no treaties linking it to or governing its operations in the law of nations.

The Bradford opinion had a single surprising revelation; it was the first time that an "uncivilized" society or nation was thrust in the spotlight of the ATS. Sierra Leone's brief fame stemmed from all the wrong reasons. It was not about people's rights in the raided settlements. The people in those settlements were black Africans, and they were at the bottom of the hierarchical human scale; in fact, they were the property of Britain, and Britain was protesting the looting of its property. Sierra Leone was a complex piece in the slavery puzzle as it was founded from the Sierra Leone Company set up by the British Parliament with the dual role of resettling freed slaves from the American revolutionary war and also promoting other trading interests for the British. Sierra Leone in the eighteenth century represented freedom from enslavement even as it promulgated a different kind of slavery.

Although Sierra Leone surfaced in the opinion as an "uncivilized" free country, Bradford was aware that a ruling in favor of privateers looting the property of Britain would cause strain in the Americans' relationship with the British and that such a ruling would breach the law of nations. Thus, Bradford observed, "[ $t]$ he transactions complained of originated or took place in a foreign country, they are not within the cognizance of our courts; nor can the actors be legally prosecuted or punished for them by the U.S." ${ }^{14}$ In other words, Bradford was confirming that the ATS was not meant for "uncivilized" nations or events that took place in "uncivilized" nations.

It is important to note both the identity of William Bradford (1755-1795) and the relationship between Britain and America during this period. Bradford was from the

71. Bradford Opinion, supra note 66, at 59; see also Ishai Mooreville, A Question of Sovereignty: The History Behind Attorney General Bradford's 1795 Opinion on the Alien Tort Statue, 40 SYR. J. I. L. 218 (2013).

72. E.g., An Act for the Punishment of Certain Crimes Against the U.S. \$8, 1 Stat. 112, 113-14 (1790).

73. See also, Curtis, supra note 58 , at 13 ("Bradford did not mention the federal piracy statue, even though the criminal statute that he did mention (the Neutrality Act) made clear that nothing in the foregoing act shall be construed to prevent the prosecution or punishment of treason, or any piracy defined by a treaty or other law of the U.S.")

74. Curtis, supra note 58, (" $[\mathrm{T}]$ he Bradford opinion provides support for the extraterritorial application of the ATS to the conduct of U.S. citizens, but not the conduct of foreign citizens. Second, the opinion does not support aiding and abetting liability under the ATS: at least as modern ATS cases have applied that concept.") 
Pennsylvania gentry, the son of a printer, in post-revolutionary America and served as the second Attorney General of the U.S. for twenty months before dying at the age of thirty-nine. His legal career flourished early, and, at age twenty-five, he became the Attorney General of Pennsylvania. ${ }^{75}$ Bradford's legal legacy is documented in West v. Barnes, ${ }^{76}$ The Neutrality Opinion, ${ }^{77}$ and An Enquiry how Far the Punishment of Death is Necessary in Pennsylvania. ${ }^{78}$ What survived of West v. Barnes showed that Bradford was on a mission for some level of equal rights, and Bradford engaged "the more critical task of balancing strict statutory interpretation with equal access to justice for the far flung citizens of the new nation." ${ }^{\text {79 }}$ This assessment would suggest that the Neutrality Opinion would at least offer some justice to the British when they protested the aiding and abetting of looting by American citizens in the British outpost of Sierra Leone.

In West v. Barnes, the Court held that a writ of error could be issued only from the clerk of the Supreme Court. Bradford at one point argued, "the principles of the common law and of the act of Congress, was a Writ of Right." ${ }^{\text {"80 }}$ Although it was a procedural case, it helped to put Bradford in the history books. While the Neutrality Opinion has been highly cited and discussed in a number of sources and even served as the opening salvo by lawyers in the Kiobel case, Bradford was perhaps more famous for his treatise on the death penalty where he fully developed his justifications for abolishing the death penalty. The treatise gave some insights into Bradford's broader thinking. For instance, Bradford argued that capital punishment was unnecessary ${ }^{81}$ and also categorized what he deemed as "degrees" of murders, concluding that the death penalty should be abolished. ${ }^{82}$ For Bradford, the U.S. was not different from Europe (excluding plantation owners and slave traders at the time), and he asserted early on that the call to "humanity and reason" was not in vain. ${ }^{83}$ Although Bradford avoided using the language of "being civilized" in the treatise, on some occasions it was not difficult to disguise his thoughts, particularly as they related to murder: "[the protection against murder] is the great of civil society and governments are bound to adopt every measure which is, in any degree, essential to its prevention." ${ }^{\prime 4}$ It was perhaps his conviction against the death penalty that made Bradford so reluctant to offer a definite position on the raid on Sierra Leone where Americans were involved.

75. Archives and Records Center, UNIV. OF PA., http://www.archives.upenn.edu/people/1700s/bradford wm.html (last visited Sept. 12, 2014); see also Biography, DEP'T OF JUSTICE, http://www.justice.gov/ag/ aghistpage.php?id=1 (last visited Sept. 12, 2014).

76. West v. Barnes, 2 U.S. 401 (1791) (known as the first recorded case before the U.S. Supreme Court).

77. Breach of Neutrality Opinion, 1 Op. Att'y Gen. 57 (1795).

78. William Bradford (Philadelphia, 1793).

79. West v. Barnes, in 6 The Documentary History of The Supreme Court of THe U.S. 1789-1800, 3-27 (Maeva Marcus et al. eds., 1998).

80. Id. at 15 .

81. Bradford, supra note 78 , at 36 .

82. Id. at 7 ("If capital punishments are abolished, their place must be supplied by solitary imprisonment, hard labor or stripes [. . .].").

83. Id. at 5.

84. Id. at 35 . 
The second way in which the Neutrality Opinion tested the ATS was through the status of the United States' international relations with Britain. ${ }^{85}$ It was still the post-revolutionary era, and Britain was mourning the loss of its largest North American colony. The U.S., eager to establish civil relations and demonstrate that it could act in the international community signed the Jay Treaty. ${ }^{86}$ In principle, the Jay Treaty's purpose was to solve issues from the Treaty of Paris, ${ }^{87}$ including a number of grievances between Britain and the U.S. like the payment of debts and the continued presence of English troops on American soil. However, it was the Neutrality Treaty that established America's position with Great Britain and the other European nations.

Spain, France, and Britain were still at loggerheads over a number of trading disputes, and the U.S., which was still in its formative years, did not want to antagonize any of these great powers. Moreover, Britain was exporting a number of items to the U.S. from its West Indian slave plantations while the U.S. was hoping that Spain would grant independence to Florida and France to Louisiana. ${ }^{88}$ These factors prompted the U.S. to maintain neutrality; when France declared war against the British it was a pivotal moment for the Americans to remain neutral despite earlier agreements to come to the aid of France in the event of war. ${ }^{89}$ The Neutrality Act created a space for the U.S. in the law of nations. ${ }^{90}$ Under the Neutrality Treaty, Americans were forbidden to wage war against any nation with which the U.S. was at peace, and it was worded to ensure that the warring factions understood that the nation was "at peace, with the belligerent powers." 91 The Neutrality Act was a skillful political document disguised to release the U.S. from its commitment to come to the aid of France. The French declaration of war against the British put the U.S. in a complicated position-its two friends were now at war-and as such, the Neutrality Act was designed to prevent the U.S. from taking sides. Although trade and sea warfare contributed to the enactment of the Neutrality Act, it was mainly passed because France and Holland declared war against the Britain. The U.S. found itself boxed in a corner with few options, and the only solution was to declare neutrality.

85. E.g., Virginia Kuhn, The Relations Between America and Britain 1791-1795, as Centered in Neutrality and the Jay Treaty, (1948) (Master's Thesis, Paper 253, Loyola University Chicago).

86. See supra note 52. It was between the U.S. and her former colonial master and aimed to promote trade and maritime conduct between the two nations. See Treaty of Amity, Commerce, and Navigation, between His Britannic Majesty and the U.S. of America, Conditionally Ratified by the Senate of the U.S., at Philadelphia, June 24, 1795.

87. Treaty of Paris (1783).

88. Kuhn, supra note 85 , at $12-14$

89. Id.; see generally Charles Hyneman, Neutrality during the European Wars of 1792-1815, 24 AM. J. INT'L L. 279 (1930); Jules Lobel, The Rise and Decline of the Neutrality Act: Sovereignty and Congressional War Powers in the States Foreign Policy, 24 Harvard INT'L L. J. 1, 24 (1983) (arguing that the main purpose of the Neutrality Act was not to protect sovereignty but rather for the U.S. to assert its authority over central government).

90. Prior to the Neutrality Act, George Washington issued the Proclamation of Neutrality in 1793.

91. Kuhn, supra note 85 (citing M. Woodbury, Public Opinion in Philadelphia, 1789-1801 ("The true nature and design of such act [neutrality] is to make it known to the powers at war and to the citizens of the country issuing the proclamation, that that country is at peace, with the belligerent powers and not obligated by any treaties to become a party to the war as an ally of either side, and that conduct must be observed conformable to the above situation and strict neutrality maintained towards both sides."). 
This sort of thinking would eventually manifest in Kiobel where enforcing the ATS extraterritoriality would have considerable foreign policy implications.

Immediately after the ATS was passed, the U.S. was eager to demonstrate through the courts and judicial opinions that it adhered to the law of nations. The delicate situation of Sierra Leone involving foreign activities in a non-European state was not the perfect case to demonstrate to the European allies that the law of nations was binding on the U.S. In the Neutrality Opinion, Bradford stayed mute on the subject. Had the same events occurred in European waters, or involved diplomats from Europe, Bradford's Opinion would likely have been different. The Marbois and van Berckel affairs are two examples of how the U.S. wanted to demonstrate that the laws of nations were binding on the U.S., but these were unique situations.

It was during this time that the ATS began its journey into irrelevance where it was almost forgotten. Prior to Kiobel, where Nigerians used the ATS to argue for crimes against humanity allegedly committed by a multinational corporation, the ATS was rescued from irrelevance by modern people of color, a mixture of Europeans and Indians of the Americas.

\section{Brownness, the Law of Nations, and How the ATS Met Filartiga and Sosa}

As the world changed dramatically in the nineteenth and twentieth centuries, the ATS was largely forgotten and even became a relic because piracy (as it had existed in eighteenth century) was no longer a problem. For over two hundred years, the ATS stayed hidden in the annals of law. Then, in 1980, the ATS reemerged. This sudden resurrection of the ATS was not brought out by European diplomats or to resolve issues concerning piracy. The resurrection of the ATS in 1980 was brought about by aliens against aliens for alleged torture committed in Paraguay. In other words, the ATS was being used by "uncivilized" aliens who straddled between black and Europeans. The resurrection of the ATS in Filartiga v. Pena-Irela signaled that the ATS was constructing the color of human rights.

In 1980 a Paraguayan political dissident, Joel Filartiga, sought damages from a former Paraguayan government official for the kidnapping, torture, and killing of his son. He blamed Americo Norberto Pena-Irala, a former Inspector General of Police in Asuncion, for causing the wrongful death of his son. It was alleged that the sixteen-year-old Joelita "was tortured and killed in retaliation for his father's political activities and beliefs." ${ }^{\prime 2}$ Despite efforts to get a remedy in Paraguayan courts, the Filartigas never had a chance because their attorney was arrested and threatened with death. Both parties in the dispute relocated to the U.S. but were unaware of each other's presence. However, when the Filartigas learned of Pena-Irala's presence in the U.S. they sought his deportation.

While in a deportation center, Filartiga served Pena-Irala with court documents demanding ten million dollars in compensatory and punitive damages in a New York court, ${ }^{93}$ claiming that the wrongful death cause was an emerging "practice constitut-

92. Filartiga, supra note 20 , at 878 .

93. Id. at 879 . 
ing the customary international law of human rights and the law of nations." 94 "The complaint was dismissed in the trial court on jurisdictional grounds ${ }^{95}$ but was appealed by the petitioners.

Although Pena-Irala was deported, Filartiga argued that the ATS granted the federal courts jurisdiction over the matter. The Second Circuit Court heard the matter. On this point, the Second Circuit, having reviewed the nature of the law of nations in American judicial history, agreed with Filartiga and explained "federal jurisdiction over cases involving international law is clear." 96 The Filartiga court declared:

[...] we believe it is sufficient here to construe the Alien Tort Statute, not as granting new rights to aliens, but simply as opening the federal courts for adjudication of the rights already recognized by international law. [.. .] There can be little doubt that this action is properly brought to federal court. This is undeniably an action by an alien, for a tort only, committed in violation of the law of nations. ${ }^{97}$

To arrive at this decision on the jurisdiction, the court examined the question of whether the conduct had in fact violated the laws of nations and explained that "an act of torture committed by a state official against one held in detention violates established norms of the international law of human rights, and hence the law of nations." "98 In a largely ignored sentence in Filartiga, the court appeared to have explained why, after two hundred years, it resurrected the ATS, reasoning that the previous ATS cases were not purely of a human rights nature.

The court opined: "the narrowing construction that the Alien Tort Statute has previously received reflects the fact that earlier cases did not involve such wellestablished, universally recognized norms of international law that are here at issue." Filartiga reintroduced the ATS in international law. But, more than that, it construed the ATS as a tool to be used when alleged torts of human rights violations were committed in another territory. This observation refers to the Filartiga court's premise that "deliberate torture perpetrated under color of official authority violates universally accepted norms of international law of human rights, regardless of the nationality of the parties." 100 This observation suggested that the court wanted to introduce the ATS as a tool to be used not only by the aliens from the "civilized" nations that historically used the ATS, but that people in other, non-European nations could also use the ATS. The "uncivilized" could now use the ATS, and this was exactly what Filartiga, a native of Paraguay and a descendant of brown natives, did.

94. Id.

95. Id. at 880 .

96. Id. at 887 .

97. Id. (citation omitted).

98. Id. at 880,81 ("The requirement that a rule command the general assent of civilized nations to become binding upon them all is a stringent one. Were this not so, the courts of one nation might feel free to impose idiosyncratic legal rules upon others, in the name of applying international law.").

99. Id. at 888 .

100. Id. at 878 . 
The Filartiga ruling had multiple effects, but primarily it brought the ATS back into the legal lexicon of the American judiciary. Now, it was being used as a tool to adjudicate human rights violations. A plethora of cases involving the ATS took place in different circuits with different interpretations of the ATS. The Supreme Court entered the ATS debate in 2004 in the Sosa decision, almost twenty years after Filartiga. Similar to Filartiga, the Sosa case involved a doctor, Huberto AlvarezMachain, who was accused of aiding and abetting the torture of a U.S. federal agent in Mexico. The U.S. was unable to get Alvarez to face trial in the U.S. despite the existence of bilateral treaties between the two countries. Mexican mercenaries like Sosa, akin to eighteenth century privateers, were hired by U.S. federal agents to kidnap Alvarez and send him to Texas where he was charged.

Alvarez was subsequently tried and acquitted. Upon returning to Mexico, he accused Sosa of violating the law of nations under the ATS by torturing him. The claim made its way to the U.S. Supreme Court. The lower courts found that the ATS created a cause of action for the alleged violation of international law. The Supreme Court reversed. According to the Court:

although the ATS is a jurisdictional statute creating no new causes of action, the reasonable inference from the historical materials is that the statute was intended to have practical effect the moment it became law. The jurisdiction grant is best read as having been enacted on the understanding that the common law would provide a cause of action for the modest number of international law violations with a potential for personal liability at the time. ${ }^{101}$

Thus, in reversing the lower courts' decision, the Sosa Court never fully settled how international law would play out in future cases such as Kiobel. Instead, it cautioned against transposing international law to "private rights." 102 The Court warned: "The creation of a private right of action raises issues beyond the mere consideration whether underlying primary conduct should be allowed or not."

According to the Court, an ATS claim is actionable if violations are within "a norm of international character accepted by the civilized world and defined with a specificity comparable to the features of the $18^{\text {th }}$ [sic] century paradigms we have recognized." ${ }^{103}$ The Sosa ruling confirmed eighteenth century paradigms of international law by finding that the ATS, when interpreted in the context of the law of nations, was only meant for the infringements of ambassador's rights, the violation of safe conducts, and piracy. ${ }^{104}$

The Sosa decision was the first time the Supreme Court entered the debate over the ATS in its modern history. Its anatomical analysis, rich in its historical context, made it clear that the First Congress wanted the courts to hear only a few "private causes of action for certain torts in violation of the law of nations." ${ }^{105}$ In this regard,

101. Sosa, supra note 20 , at 724 .

102. Id. at 728 .

103. Id. at 725 .

104. Id. at 715 (citing Blackstone, who commented on three specific offenses against the law of nations and was addressed by the criminal law of England).

105. Id. at 724 . 
one may conclude that the torts resulting from human rights violations committed by aliens were not one of those limited torts. The aliens concerned in the Sosa case were Mexicans-it was Mexican against Mexican, but they resorted to the domestic laws of the U.S. to seek justice. The Mexicans, like the aliens in Filartiga, are descendants of the Native Americans . . . brown people.

\section{God, the ATS, and the Oil Fallacy in Sudan}

Who are modern day pirates? Are they oilmen from western-based corporations, or are they men of the cloth, armed with the Bible in one hand and the rhetoric of human rights in the other preaching to the "ungodly" and "uncivilized" in countries such as Sudan? There is one particularly odd case that connects the ATS to religion. In Presbyterian Church of Sudan v. Talisman Energy, ${ }^{106}$ the ATS was invoked and the courts addressed liability for aiding and abetting human rights violations. The Supreme Court declined to hear the case in October 2010. I will discuss the Second Circuit's opinion of 2009. From the very beginning of this case, when it was heard in a New York court in 2003, the allegations were not so different from those in Kiobel, which at that time had begun to work its way through the courts. The allegations read as if the corporation at the center of the dispute, Talisman Energy, was a historical colonial master because the corporation was accused of gross violations of human rights and enslavement; these were the same kind of allegations issued against historical colonial powers. ${ }^{107}$

This case is somewhat peculiar, but when fully analyzed, the facts are not necessarily different from those of Bolchos in the eighteenth century; two elements connected this case to Bolchos. The first was war, in the sense that a civil war was ongoing in Sudan when this case was litigated; in Bolchos, both Spain and France were at war. The second connection is the role of people of color. In Bolchos, "negroes" were property and, as such, were fought over in a court. In the present case, the allegation of human rights abuses were levelled against the Sudanese government-aided and abetted by Talisman-by a black congregational group in the Upper Nile province of Sudan.

The corporation at the center of the allegations was the Canadian company Talisman Energy, whose crimes were similar to those allegedly committed by Shell in Nigeria in the Kiobel case. Talisman Energy was accused of aiding and abetting the Sudanese government in violating customary international law and other crimes against humanity. A reverend and his flock from a Christian church in the Upper Nile Region of Sudan - the Presbyterian Church of Sudan ("PBCS"), an unincorporated association of people of the Presbyterian faith who are, or were, residents of Sudan, made the allegations. ${ }^{108}$

106. Presbyterian Church of Sudan v. Talisman Energy, Inc., 582 F.3d 244 (2d Cir. 2009).

107. Presbyterian Church of Sudan v. Talisman Energy, Inc., 244 F. Supp. 2d 289, 296 (S.D.N.Y., 2003) ("Plaintiffs allege that defendants collaborated to commit gross human rights violations, including extrajudicial killing, forcible displacement, war crimes, confiscation and destruction of property, kidnapping, rape, and enslavement.")

108. Id. at 302 . 
The case traversed the courts from 2003, with rulings in $2005,{ }^{109} 2006,{ }^{110}$ and the current one under discussion in this section. The legal instrument of choice for the allegations was the ATS. The Second Circuit dashed the hopes of the PBCS when it ruled that international law must determine the standard for aiding and abetting liability. The court found that "the standard for imposing accessorial liability under the ATS must be drawn from international law; and that under international law, a claimant must show that the defendant provided substantial assistance."111

One of the more interesting observations about the PBCS dispute is that the petitioners were embarking on a mission to right the wrongs of modern slavery. The petitioners alleged that modern slavery was taking place with the help of Talisman Energy and that such practices should be stopped. Moreover, they sought financial compensation, as if to have the west atone for its history of enslaving Africans. The PBCS, however, failed to connect the ATS to slavery itself, making it difficult for courts to rule in PBCS's favor. But, in short, the PBCS depicted the fallacy of using the ATS as a human rights tool. I develop the concept of lex internationalis to describe the dual nature of human rights practice and application in international law. On the one hand, "civilized" nations use the language and rhetoric of human rights to "civilize," correct past injustices, and participate in international law, while on the other hand, victims of human rights use human rights rhetoric to seek remedies and compensation from western states and corporations. This dual nature creates a lex internationalis regime of human rights.

\section{IS HuMAN RigHTS LEX INTERNATIONAIIS? KIOBEL, THE ATS, AND THE LAW OF NATIONS}

The concept, usage, interpretation, and practice of human rights in international law have gone beyond the time when western societies viewed human rights as a rhetorical tool when trying to assimilate "uncivilized" people into the western vision of how society functions and the rule of law. In international law, human rights have become a muddied concept, and the lines are blurred between how, when, and to whom human rights causes of action are available. Furthermore, human rights in international law have carved out a huge slice of international legal discourse that is in some way lex internationalis, a sort of unique duality in which the "civilized" rely on human rights rhetoric to legitimize their participation in international law, while the "uncivilized" see human rights as a weapon to gain financial or moral compensation from western actors, states, and corporations. In Kiobel, the petitioners sought remedy for the alleged violation of their human rights. The Supreme Court ignored the concept of human rights abuses, however, and instead focused on how the ATS was perceived in international law.

109. 374 F. Supp. $2 d 331$ (S.D.N.Y. 2005).

110. 453 F. Supp. 2 d 633 (S.D.N.Y. 2006).

111. 582 F. $3 \mathrm{~d}$ at 247 . 


\section{A. Background to the Kiobel Litigation in the Supreme Court}

When the ATS was revived in American courts it was primarily used as a tool by human rights litigants to bring charges against a foreign person or corporation for crimes committed outside the U.S. The ATS was no longer about violating diplomatic premises or acts of piracy on the high seas. Eighteenth century international law was no longer fashionable. Gone was the law of nations and replacing it was its modern incarnation - international law - and, in particular, human rights law.

The narrative behind Kiobel began with the Ogoni people, who are based in the Delta region of Nigeria. In the 1990s, the petitioners resided in Ogoniland, and a subsidiary of the Anglo-Dutch petroleum company, Shell, was incorporated and operating in the Niger Delta Region of Nigeria. It was searching for oil and production capacity in Ogoniland. The subsidiary, Shell Petroleum Development Company of Nigeria Ltd., was blamed for a number of oil spills, which allegedly created a big environmental impact. The Ogonis began demonstrations against Shell and its practices, and, according to court documents, Shell sought the support of the Nigerian government "to violently suppress the burgeoning demonstrations." 112 Shell was blamed for aiding and abetting a number of human rights violations allegedly committed by the Nigerian military and police against the Ogoni people such as "beating, raping, killing, and arresting residents." 113 After some time, the petitioners moved to the U.S., where they gained political asylum and became legal aliens. With these new statuses, they sued Shell in a New York Court "alleging jurisdiction under the Alien Tort Statute" and sought relief under customary international law. ${ }^{114}$

The Supreme Court seemed unconcerned with the alleged human rights abuses. Instead, the main issue for the Supreme Court was whether the ATS could be applied extraterritorially. Thus, the Supreme Court asked the parties to provide additional briefs as to "whether and under what circumstances the [ATS] allows courts to recognize a cause of action for violations of the law of nations occurring within the territory of a sovereign other than the U.S." 115 The Supreme Court addressed this issue and tossed aside the Ogoni's main concern that Shell aided and abetted a number of human rights violations. ${ }^{116}$ The Court held that the ATS could not be applied extraterritorially, and there was no presumption that it did: "[The presumption against extraterritoriality] provides that when a statute gives no clear indication of an extraterritorial application, it has none." 117 By finding that under American law there was no corporate liability for human rights violations committed in other sovereign states' territories, the Court has put into question the nature and status of the ATS.

Is Kiobel the death knell of the ATS, or do future human rights litigants have hope? Most importantly: why has human rights litigation under the ATS become a

112. Kiobel, 133 S. Ct. at. 1662.

113. Id.

114. Id.

115. Id. at 1663 .

116. Id.

117. Id. at 1664 (citation and quotations omitted). 
color issue? Color in the sense that it is people of color in developing nations using it as a tool to seek remedy against western corporations or the U.S. government.

The Kiobel case has been explored in a number of symposiums and special editions of law journals. But I want to address the color of human rights against the backdrop of empire, civilization, and race. My subjective analysis is an attempt to address what got lost in Kiobel and place an emphasis on a single point: the color of human rights. This is largely addressed in the next section, following an analysis of Kiobel.

\section{B. The Supreme Court and the Effort to Minimize International Discord in Kiobel}

When the U.S. enacted the ATS in the eighteenth century, its primary purpose was to minimize international discord by providing legal remedies for Europeans working in the U.S. The French, Dutch, and British were empires in the twilight of their glory days; Britain had just lost the revolutionary war and the law of nations was about to forever change in that it would, for the first time, include a major player that was not in Europe; the U.S. judiciary and legal scholars saw a way to join the family of nations through the ATS. Through this statute, the U.S. could prevent or minimize any form of international discord. In the twenty-first century, the Kiobel decision reflected this same concern: it aimed to prevent or minimize international discord, and, towards that end, ruled that if human rights abuses were committed abroad, it would not be the prerogative of the ATS to address such claims.

The Court first addressed the issue of presumption against extraterritoriality. ${ }^{118}$ For the Court, addressing the presumption against extraterritoriality would allow it to dismiss the claims of human rights violations allegedly committed abroad. It was not the first time that the Court had been hesitant in finding an implied right of action in the absence of an express right. In Alexander v. Sandoval, ${ }^{119}$ the Supreme Court did not find an implied right of action, and, in Kiobel, the Court explained that it wanted to prevent a clash between American law and those of other countries:

[T] his presumption [against extraterritorial application] serves to protect against unintended clashes between our laws and those of other nations which could result in international discord. [. . .] The ATS, on the other hand, is strictly jurisdictional. [...] It does not directly regulate conduct or afford relief. It instead allows federal courts to recognize certain causes of action based on sufficiently definite norms of international law. But we think the principles underlying the canon of interpretation similarly constrain courts considering causes of action that may be brought under the ATS. ${ }^{120}$

Similar concerns were also raised in Morrison v. Australian National Bank, ${ }^{121}$ where the Supreme Court found that the Securities and Exchange Act (1934) did not

118. Kiobel, 133 S. Ct. at 1664; see also, William Dodge, Understanding the Presumption Against Extraterritoriality, 16 BERKELEY J. INT'L L. 85, 88 (1998) (explaining the presumption against extraterritoriality means (1) conduct, (2) effects and (3) having an effect in relation to the U.S.).

119. Alexander v. Sandoval, 532 U.S. 275, 293 (2001) (finding that "an intent to create a freestanding private right of action to enforce regulations [. . . ] no such right of action exists").

120. Kiobel, 133 S. Ct. at 1664 (citations and quotations omitted).

121. Morrison v. National Australia Bank Ltd., 561 U.S. 247 (2010). 
apply extraterritorially for securities fraud committed abroad. ${ }^{122}$ The ATS and the presumption against extraterritoriality has always been a contentious issue in American jurisprudence, ${ }^{123}$ which played out in the Court's reasoning. The ruling contained divided opinions from the conservative and liberal wings of the Court, ${ }^{124}$ but the Court's decision was unanimous. Chief Justice Roberts penned the opinion. On the other hand, the liberal wing of the Court, in Justice Breyer's concurrence, championed the cause of international law and argued that claims for violations of international law could be recognized under the ATS. Thus, the Court arrived at the same conclusion but with different arguments.

International law is a hotly contested field in the U.S. The debate ranges from whether international law is really law to whether there is such a thing as international law as opposed to transnational law. Semantics aside, in the U.S., international law has its origins in the enactment of the ATS and eighteenth century law of nations. The ATS was born out of the need to be a part of the "civilized" international community that existed in the eighteenth century, whose interstate affairs were regulated by the so-called law of nations. The law of nations has morphed into what American legal scholars refer to as transnational law-a jurisprudence that covers every facet of law from the law of nations, comparative law, foreign law, and international law. It was with the ATS that Americans were introduced to international law. American notions of international law are still framed by how they conceive of and interpret the ATS, because it is the ATS that spells out, in black and white terms, the notion and meaning of international law from an American perspective.

In Kiobel, the Supreme Court wanted to minimize the potential discord in its foreign relations. Therefore, it removed the core concern of the Ogonilians, and their plea for humanity went unanswered. But this was not surprising when the events during the early days after the passage of the ATS were taken into account, such as the Neutrality Opinion or the Bolchos case concerning the human cargo. The Neutrality Opinion and the Kiobel case have some striking similarities: the major actors were black Africans, although in the Neutrality Opinion, the Africans concerned were property of Great Britain via the Sierra Leone Company Ltd., and in Kiobel, the Africans lived or worked in an area in Africa where a multinational corporation conducted its business. The Africans in Kiobel also escaped persecution in Nigeria and settled in the U.S. as legal alien residents. But in the context of the Bradford Opinion, the Africans were considered "uncivilized," and arguably, as subjects of former empires; the Ogonis of Nigeria in Kiobel were also "uncivilized". In Kiobel, the other major actor was the Anglo-Dutch Company, Shell, which can be considered a modern day empire. The Kiobel petitioners wanted to apply the ATS in a modern human rights context; ironically, when the ATS was enacted in the eigh-

122. Id.

123. E.g., EEOC v. Arabian Am. Oil Co., 499 U.S. 244 (1991).

124. The Chief Justice's majority opinion was joined by Thomas, Alito, Scalia, and Kennedy who believed the ATS was only necessary if the claims had significant connection to the U.S., while Justice Breyer penned a concurrence with different reasoning and was joined by Sotomayor, Kagan, and Ginsburg. 
teenth century, there was no concern for or conception of human rights. Slaves were property, and they could not have argued such a case.

One may deduce that the prowess of multinational corporations won the day in Kiobel when the Court held that they were not liable for violations of human rights obligations. From the plaintiffs' perspective, the case was about human rights, but as it turned from the Supreme Court's reasoning, American interests, as embodied in the form of multinational corporations, were also at stake. The ATS granted the multinational corporations safe harbor under international law from human rights fundamentalists. If multinational corporations are now the new empires, taking the reins from their eighteenth century counterparts, then multinational corporations also have a human rights obligation in the territories in which they operate. In many cases, multinational corporations have become the new privateers, the new kings of empires, with royal prerogatives to pursue profits and plunder economic wealth. However, they can find safe harbor in the comfort of international law and their home states' domestic laws. Today's multinational corporations are the new British East India Trading Company or the Dutch East India Company, the most powerful companies in the eighteenth century, and probably the kind of entities that the ATS was supposed to find liable. Thus, when the Kiobel Court inquired about the identity of modern day pirates, ${ }^{125}$ the answer was right under its nose; multinational corporations that aided and abetted human rights atrocities should be accountable for those atrocities. This was the Ogonilians' core concern. Multinational corporations, then, are modern day pirates, ${ }^{126}$ but when the Ogonilians raised concerns about human rights atrocities, they were never heard.

It was perhaps the concurrence of Justice Kennedy that reminded the Court that the case was in fact about human rights. ${ }^{127}$ Justice Kennedy opined that "many serious concerns with respect to human rights abuses committed abroad" were still within the purview of legislation, but some further elaborations and explorations were warranted. ${ }^{128}$ There were also further human rights concerns raised in the Court's concurrence when it acknowledged certain behaviors that were "analogous" to piracy or that the slave trade must not be overlooked, and that the application of the ATS could be informed by "international substantive norms." ${ }^{129}$ Arguably, then, taking Justice Kennedy's arguments in mind, the human rights violations in the plaintiffs' complaint were analogous to heinous crimes, such as piracy and the slave trade. The ATS is equipped to fight that war and should not turn a blind eye to such violations of human rights. ${ }^{130}$ But unfortunately, the Supreme Court was concerned

125. Kiobel, 133 S. Ct. at 1671-72, (stating that today's pirates are "torturers and perpetrators of genocide").

126. See also Jennifer Karnes, Pirates Incorporated?: Kiobel v. Royal Dutch Petroleum Co. and the Uncertain State of Corporate Liability for Human Rights Violations under the Alien Tort Statute, 60 BUFF. L. REV. 823 (2012).

127. Kiobel, 133 S. Ct. at 1669.

128. Id.

129. Id at 1673 .

130. Id. at 1674 
about the foreign policy implications an extraterritorial application of the A'TS might have caused.

Nevertheless, one should not forget that the ATS falls within a set of laws that can be construed as applicable extraterritorially. The problem with applying U.S. domestic law extraterritorially is that it creates tension within international law. ${ }^{131}$ Is international law in the rest of the world the same as in the U.S., or can the U.S. ignore the law of nations it once passionately embraced? Or, do U.S. laws have a transnational effect? Kiobel provides a platform to address some of these questions in a different context. The judicial history of the ATS reveals that race is inextricably linked to the ATS as reflected by decisions such as Bolchos and the Bradford Opinion, which were reached immediately after the passage of the ATS. When the ATS was resurrected, its focus was race and human rights, and it is that linkage whereas human rights are lex internationalis, a concept that highlights the hypocrisy in human rights. This hypocrisy at the global level is now building a color of human rights where human rights are a rhetoric for the "civilized" and whose imperialist ambitions are kept alive in multinational corporations, while at the same time, the "uncivilized" adopt the language and rhetoric of human rights as a tool for financial compensation. The color of human rights increasingly reflects situations in which only ethnic minorities litigate human rights violations under the ATS.

\section{Lex Internationalis and the Color of Human Rights}

Back in the eighteenth century, the law of nations was primarily a tool to regulate the international relations of European nations. However, by the end of the twentieth century, the world changed dramatically and the law of nations was no longer a tool for European states' relationships with one another. Now it encompassed the entire globe. Much like its predecessor, current international law has a hierarchical structure that closely resembles its eighteenth century counterpart.

One area in the hierarchical structure of international law is that of international trade law and human rights law. The former has become a global project and is plagued with several criticisms. One such criticism is that international trade law is an imperialist project of the west, while the latter, international human rights law, emerged in the post-1945 era, as a tool to deal with displaced Europeans after the Second World War. Today, human rights law has morphed into a tool used by western and European citizenry to engage with the "uncivilized" people of former colonies in places such as Africa. People from developing nations use human rights as a language and tool to seek judicial remedies from western-based corporations or governments. Furthermore, the language and rhetoric of human rights is used by countries to legitimize their participation in the contemporary international legal system and helps to create a system where human rights become lex internationalis. As described previously, lex internationalis refers to the dual nature of human rights law in which the "civilized" can rely on human rights as a tool of rhetoric to legiti-

131. See also Adamski, supra note 35, at 1537 (arguing that multinational corporations should not be liable under the ATS as this helps to avoid "American judicial imperialism"). 
mize their participation in international law, while people from developing nations see human rights as a means of gaining financial or moral compensation from western actors and corporations.

One particular set of actors in the lex internationalis human rights regime are non-western. People of color use international human rights law under the ATS as a sort of affirmative action. The representarive sample of human rights cases in international law where the ATS was invoked concerned people of color from developing nations. ${ }^{132}$ In other words, the plaintiffs in human rights cases, such as Kiobel or Sosa, either are from former colonial holdings or are racial minorities in the society where they pursue these human rights claims. It is the people who belong to non-western nations, or on occasion, the minority people in western nations, who often pursue human rights claims under the ATS.

When an individual makes a human rights claim in a court, that individual will often belong to a minority race or ethnicity—a so-called alien making the claim based on the legal traditions of the U.S. In cases such as Filartiga and Sosa, for example, the ATS was resurrected by people of color. In Kiobel, the petitioner was an alien resident in the U.S.

The situation gets a bit murky when human rights claims are made by a private corporation or when a corporation is the respondent in a human rights claim. Although it is often unheard of for corporations to bring a human rights claim against a state or an individual, as a respondent, a private corporation would want to settle such a claim or throw its financial might against a good legal defense. This would make the situation a win-win for the corporation as it avoids a public relations disaster, and it can argue that domestic laws are not applicable to the corporation if it conducts business in another state. Furthermore, a private corporation in a lawsuit where human rights claims and counterclaims are involved can benefit from either being registered in both a western or non-western state. For the latter, that state would want to avoid a fall-out where jobs and millions of dollars are invested. For the former, the state would want to protect its corporations from leftist and hawkish human rights activities that are deemed harmful to business operations. The western state would also be concerned with trade and investment implications.

These issues raised a number of legal questions under international law. Where international law is presumed to be weak or fraught with political implications, one natural way to respond to legal problems that present themselves is to apply the domestic law of the state that is involved. But herein lies the irony. Some states are already equipped to deal with so-called human rights violations with various legal instruments. For example, under English Common Law, a claim of human rights could be dealt with under laws of negligence, which was part of the broader spectrum of tort law. Similarly, in the civil law systems of Europe, legal instruments such as

132. E.g., In re South African Apartheid Litigation, 617 F. Supp. 2 d 228 (S.D.N.Y. 2009); Presbyterian Church of Sudan v. Talisman Energy, Inc., 244 F. Supp. 2 d 289 (S.D.N.Y 2003); Roe I v. Bridgestone Corp., 492 F. Supp. 2d 988 (S.D. Ind. 2007) (where a foreign subsidiary allegedly forced children in Liberia to work full-time on a plantation). 
Brussels I and $\mathrm{II}^{133}$ could respond to a Kiobel-type situation. However, caution must be taken when using the law of a state to respond to a problem in another sovereign state since this raises a whole set of problems under international law and involves the application of that state's law extraterritorially as was seen in Kiobel. But, in Kiobel, the problem was the ATS. In this case, the ATS had limited utility because it was created to respond to specific eighteenth century problems such as piracy and the abuse of diplomats.

Because the ATS was largely forgotten for over two hundred years, the U.S. was suddenly confronted with its role and the application of the ATS in international law by Filartiga. But because some states' laws were enacted to present "modest [...] international law"134 remedies for violations of laws in another state, the U.S. faced a dilemma when it came to the application and interpretation of the ATS.

According to Justices Alito and Thomas, who concurred with the Court in Kiobel, the ATS was created only for the "violation of safe conducts, infringement of the rights of ambassadors, and piracy," and as such, "private claims under federal common law for violations of any international law norms" that do not meet "definiteness and acceptance among civilized nations" should not be recognized. ${ }^{135}$ In other words, the ATS was not intended to address human rights claims, particularly if those claims are from "uncivilized" aliens whose states were not seen as part of the fabric of civilized society in the eighteenth century when the ATS was passed. This, then, begs the question: what is the color of human rights?

One answer suggests that the color of human rights depends on whether a particular state's interests are at stake in an international or domestic jurisdictional litigation. In this context, the individual's interests are disregarded, and the color of human rights becomes purely the interest of states. Despite the fact that the ATS has been seen as a useful tool to provide relief for those present on American soil who make claims for tortious violations abroad, the ATS was only meant for the "civilized," and its passage was meant to reflect that. Both the French Ambassador and the Dutch diplomatic envoy in New York were unable to get relief prior to the passage of the ATS, and an embarrassed U.S. acted to ensure that "civilized people" were able to get judicial relief. ${ }^{136}$ This relief, however, was not applicable to the "uncivilized" who had no place in eighteenth century international law and relations.

In Kiobel, the primary interests at stake were personal, and the plaintiffs were essentially "uncivilized" nationals residing in a "civilized" state. This creates two problems. The first is that as "uncivilized" alien residents, they have exhausted the U.S.'s judicial process to the point that even if there was a favorable decision in the case, it would have caused a political shift in American foreign relations that was not worth the diplomatic and political consequences. The Kiobel Court labelled such

133. Council Regulation (EC) 44/2001 2000 J.O. (12).

134. Kiobel, 133 S. Ct. at 1663.

135. Id. at 1670 .

136. Id. at 1668 ("The U.S. was [. . .] embarrassed by its potential inability to provide judicial relief to foreign officials injured in the U.S. [. . . The ATS ensured that the U.S. could provide a forum for adjudicating such incidents."). 
anticipated fall-out as "international discord" and noted that such discord would have "adverse foreign policy consequences." ${ }^{137}$ The Justice Department had warned in an amicus brief that suits involving "foreign" parties were not the concern of the U.S., ${ }^{138}$ and it was a point that the Kiobel Court would later agree with when it observed that "all the relevant conduct took place outside the U.S." ${ }^{39}$ Furthermore, on a related point of "transitory torts," ${ }^{40}$ which the Ogonilians also pushed for, the Court, in what can be seen as condescending language, stated that if the actions had occurred "in another civilized jurisdiction"141 then there would be no problem in allowing a party to recover.

A second problem is the national interest of the state whose legal process the alien residents have exhausted. In this case, the Supreme Court did not believe that there was a legitimate American interest at stake, especially when compared to the events of the eighteenth century involving the French and Dutch diplomatic envoys. The Court believed that there was a lack of "distinct [American] interest;" if, on the other hand, there were American interests at stake, ${ }^{142}$ one could make the argument that the Supreme Court could have found in favor of the plaintiffs, for example, if the offenses occurred on American soil or the plaintiffs were American citizens. ${ }^{143}$ This would of course largely depend on the definition of American interests. Yet, these scenarios could create disharmony within the law-a division of rights-where one set of individual rights are superior to those of other individuals; superior rights of citizens can be constitutionally protected, however alien residents' rights are not necessarily mandated by the Constitution or by customary international legal norms.

A dilemma could emerge if the petitioner was a corporate entity from a "civilized" nation operating in an "uncivilized" state and initiated a claim against that state by using the laws of its so-called "civilized" home country. ${ }^{144}$ It would have been

137. Kiobel, 133 S. Ct. at 1664; see Robert Knowles, A Realist Defense of the Alien Tort Statute, 88 WaSH. U. L. REV. 1117 (2011).

138. Supplemental Brief for the U.S. as Amicus Curiae in Partial Support of Affirmance at 13, Kiobel v. Royal Dutch Petroleum Co., 133 S. Ct. 1659 (2013) (No. 10-1491) (noting “foreign plaintiffs are suing foreign corporate defendants for aiding and abetting a foreign sovereign's treatment of its own citizens in its own territory").

139. Kiobel, 133 S. Ct. at 1669.

140. Id. at 1666. "Civil actions for personal injury torts are transitory in that the tortfeasor's wrongful acts create an obligation which follows him across national boundaries," and transitory torts require (1) personal jurisdiction over the defendant, (2) the tort must violate the laws of the tortfeasor's state, and (3) the policies of the forum must be consistent with foreign law. See Michael Small, Enforcing International Human Rights Law in Federal Courts: The Alien Tort Statute and the Separation of Powers, 74 GEORGETOWN L. J. 163, 178 (1986); Chimene Keitner, State Courts and Transitory Torts in Transnational Human Rights Cases, 3 U.C. IRV. L. REV. 81 (2013).

141. Kiobel, 133 S. Ct. at 1666.

142. Id. at 1671 (Justice Breyer concurring and noting that there was a lack of distinct American interest) ("I would find jurisdiction under [the ATS] where (1) the alleged tort occurs on American soil, (2) the defendant is an American national, or (3) the defendant's conduct substantially and adversely affects an important American national interest, and that includes a distinct interest in preventing the U.S. from becoming a safe harbor [. . .] for a torturer or other common enemy of mankind.").

143. Id.

144. Id. (suggesting if there was a connection with the territory of the U.S., then sufficient force could be applied: "[ . . .] touch and concern the territory of the U.S. [. . .] with sufficient force [. . .]"). 
unlikely that Shell would want to sue Nigeria for human rights violation but such aspirations should not be dismissed as utopian. Kiobel created a paradox for human rights litigation against corporate entities operating in foreign states; if the plaintiffs were of "civilized" stock, there would have been a presumption that civilized nations' laws were applicable extraterritorially. For the Ogonilians, their struggle to be compensated for years of oppression went unnoticed even when they invoked circumstances that interpreted the ATS in their favor. Attorney General Bradford's eighteenth century opinion stated: "there can be no doubt [...] individuals who have been injured by these acts of hostility [French and American privateer raids] have a remedy [...] in the courts of the U.S." ${ }^{145}$ This reasoning injected confidence in the Ogonilians that they would triumph over their contemporary oppressors. ${ }^{146}$ Those hopes were dashed when the Court argued that the ATS was not intended to create a safe haven for enforcing customary international law, ${ }^{147}$ and it left the international legal community analyzing and interpreting the ATS and questioning its relevance.

A different transnational court, such as the European Court of Human Rights (ECtHR), would come to a different conclusion than the Supreme Court. A true human rights court would have ensured that the primary concerns of the Ogoniliansthe abuse of their human rights, which Shell aided and abetted—would be recognized while delicately evading the corporate liability issue in more technical prose that would have allowed both parties to emerge as winners. When the European Commission intervened in the proceedings with an amicus brief, it cautioned on how international law should be applied and argued that the ATS "should be interpreted by reference not only to the substantive, but also to the jurisdictional limits, set forth by the law of nations." ${ }^{148}$ This view ${ }^{149}$ was shared by Justice Breyer, who was leaning towards similar arguments, and opined that an approach consistent with the practice of other nations would have been preferable. ${ }^{150}$

Kiobel failed to solve one basic problem, the problem that concerned the Ogoni

145. Id. at 1668 .

146. In fact, a voice of hope was echoed back in Filartiga, where the Judge wrote a compelling closing argument. Filartiga, 630 F. 2d at 890 ("In the twentieth century the international community has come to recognize the common danger posed by the flagrant disregard of basic human rights and particularly the right to be free of torture. Spurred first by the Great War, and then the Second, civilized nations have banded together to prescribe acceptable norms of international behavior. From the ashes of the Second World War arose the United Nations Organizations, amid hopes that an era of peace and cooperation had at last begun. Though many of these aspirations have remained elusive goals that circumstance cannot diminish the true progress that has been made. In the modern age, humanitarian and practical considerations have combined to lead the nations of the world to recognize that respect for fundamental human rights is in their individual and collective interest. Among the rights universally proclaimed by all nations, as we have noted, is the right to be free of physical torture. Indeed, for purposes of civil liability, the torturer has become-like the pirate and slave trader before him-hostis humani generis, an enemy of all humankind. Our holding today, giving effect to a jurisdictional provision enacted by our First Congress, is a small but important step in the fulfillment of the ageless dream to free all people from brutal violence.").

147. The precise words of the Court were: "There is no indication that the ATS was passed to make the U.S. a uniquely hospitable forum for the enforcement of international norms." Kiobel, 133 S. Ct. at 1668.

148. Brief of the European Commission on behalf of the European Union as Amicus Curiae in Support of Neither Party, Kiobel v. Royal Dutch Petroleum Co., 133 S. Ct. 1659 (2013) (No. 10-1491) 2012.

149. Id.

150. Kiobel, 133 S. Ct. at 1677 (citing European Commission Brief, supra note 148, at 14 and arguing that 
people: Did Shell aid and abet alleged human rights violations against the Ogonilians? If so, were there legitimate human rights concerns at stake for the Ogonilians? The Court avoided those questions and Ogonilians were once again battling the dark forces of multinational corporations that aided and abetted human rights violations. Kiobel also shifted concerns of human rights from what was previously an academic and largely moot topic — corporate liability under the ATS—-to a real awakening of multinational corporations' moral and ethical obligations. In this grand tectonic shift, what was a human rights case was lost in the Supreme Court, notwithstanding the more than one hundred amicus curiae briefs submitted by human rights organizations, scholars, and even former Jewish residents of Iran. ${ }^{151}$

Both international and transnational human rights litigations against multinational corporations have now created a lex internationalis of human rights claims under international law. This is also aided and abetted by the amount of non-western participants in the human rights regime where they view human rights claims as a form of affirmative action. This is an unfortunate development for international human rights law, despite my own critical views of that regime.

Nevertheless, Kiobel unmasked the color of human rights and a yearning for the glory days of empire. Empires meant that "uncivilized" places could be looted and pillaged; profits, property, and enrichment were relentlessly pursued through slave labor. In addition, individual pirates could receive royal authorization to loot countries' wealth, and a new breed of privateers was born, while, at the same time, heinous atrocities were committed. The Ogonilians in Kiobel believed that they were wronged, and only the Supreme Court could change their fate. They were deeply disappointed, however, and thus were left to contend with the modern-day empires-westernbased multinational corporations.

In an uncanny way, modern multinational corporations are seen as a form of empire, and they operate with unlimited access in most countries of the world, spreading contemporary mercantilism, and are as powerful as states, often despised in their quest to "plunder," "loot," and aid and abet heinous crimes reminiscent of colonial days. ${ }^{152}$ The people of the Nigeria Delta in Kiobel wanted to tell the tale of such violations.

\section{CONCLUSION}

This article paints a picture in which international law has created a hierarchical structure where human rights have become a pawn in international law for different outcomes and purposes. Furthermore, the article also shows that the ATS, as an

\footnotetext{
"universal criminal jurisdiction permits a State to prosecute condemned international crimes even when committed by aliens against aliens in the territory of another sovereign").

151. Brief of Eleven Jewish Former Residents of Iran Whose Family Members "Disappeared", as Amici Curiae in Support of Petitioners, Kiobel v. Royal Dutch Petroleum Co., 133 S. Ct. 1659 (2013) (No. 10-1491), 2012 (noting that the Court should apply the ATS "to events transpiring within the Territory of a Sovereign other than the U.S.").

152. See Kiobel, at 1662 (noting in particular, the "beating, raping, killing, [. . . ] and destroying or looting property").
} 
international legal instrument, was not created to be used as a human rights instrument for the people of color or aliens in foreign territories who are not of "civilized" stock. Rather, the ATS was meant as tool for cementing the civil relationship between eighteenth century Europe and the fledging republic of America.

There are two parallel episodes in the life of the ATS in the courts that indicate the ATS created a color of human rights standard in international law. The two episodes are strikingly similar and yet are centuries apart. The first episode was the wave of cases involving the ATS in the latter part of the eighteenth century, such as Bolchos v. Darrel and the Bradford Opinion, which showed and linked the ATS to Africans and the ownership of property. The second parallel episode in the life of the ATS occurred two hundred years later, beginning with Filartiga in the 1980s through Kiobel in 2013, where, ironically, people of color in the U.S. used the ATS as a form of remedy for human rights violations committed abroad.

The ATS must be repealed. It is a relic with no modern function other than giving false hope to human rights litigants. In Kiobel and other cases, aliens sued aliens, corporations, ${ }^{153}$ or states for their complicity in human rights violations. They embarked on lengthy legal battles in U.S. courts, only to be told at the end of the process that the ATS is not applicable to alleged human rights abuses because it would distort the foreign relations of the U.S.

Despite Kiobel's failure to solve the basic human rights concerns of the Ogonilians, I believe that Kiobel has done one positive thing for the extraterritorial applicability of American laws. Formerly, American law was presumed to have had extraterritorial application, but since Kiobel, that presumption has been extinguished. Thus, Kiobel has saved U.S. law from itself and has provided an avenue through which real international law can solve some of the questions Kiobel raised, such as whether corporations are liable for human rights abuses in a sovereign state. Perhaps an international treaty can provide the answer.

153. For example, one study has found more than one hundred and fifty ATS cases against corporations from 1789-2010: "To date, plaintiffs have filed more than 155 ATS cases against corporations, with 125, approximately 80 percent of all actions, arising in the past fifteen years." Jonathan C. Drimmer and Sarah R. Lamoree, Think Globally, Sue Locally: Trends and Out-of Court Tactics in Transnational Tort Actions 29 BERKELEY J. INT'L LAW 456, 460 (2011) (citation omitted). 